\title{
E-Lections: Voting Behavior and the Internet
}

\author{
Oliver Falck ${ }^{*}$, Robert Gold ${ }^{\ddagger}$, Stephan Heblich ${ }^{\dagger}$
}

April 2012

\begin{abstract}
*University of Munich, Ifo Institute, and CESifo. Address: Poschingerstr. 5, D-81679 Munich (Germany), Phone: +49 899224 1370, Email: falck@ifo.de

${ }^{\ddagger}$ Max Planck Institute of Economics, Entrepreneurship, Growth, and Public Policy Group, Kahlaischestr. 10, D-07745 Jena (Germany), Phone: +49 3641686 733, Fax: +49 3641686 710, Email: gold@econ.mpg.de.

${ }^{\dagger}$ University of Stirling, IZA, and SERC. Address: Division of Economics, Stirling, FK9 4LA (UK), Phone: +44 178646 7481, Email: stephan.heblich@stir.ac.uk.
\end{abstract}

Acknowledgments: We thank Sascha Becker, Nina Czernich, Rob Fairlie, Ronny Freier, Bob Hart, Tarjei Havnes, Jed Kolko, Fabian Waldinger, Ludger Woessmann and seminar participants at the University of Munich (LMU), University of Jena, University of Stirling, and the Christmas meeting 2011 of the German Speaking Economists abroad for insightful comments and suggestions. We further thank Deutsche Telekom AG for providing data on the voice telephony network and IVW for providing data on newspaper circulation. 


\title{
E-Lections: \\ Voting Behavior and the Internet
}

\begin{abstract}
This paper analyses the effect of information disseminated by the Internet on voting behavior. We address endogeneity in Internet availability by exploiting regional and technological peculiarities of the preexisting voice telephony network that hinder the roll-out of fixed-line broadband infrastructure for high-speed Internet. We find small negative effects of Internet availability on voter turnout, and no evidence that the Internet systematically benefits single parties. Robustness tests including placebo estimations from the pre-Internet era confirm our results. We relate differences in the Internet effect between national and local elections to a crowding out of national but not local newspapers.
\end{abstract}

JEL Codes: D72, C50, L86

Keywords: Elections, Political Economy, Mass Media, Internet 


\section{Introduction}

A growing body of literature analyses the political economy of mass media. This literature shows that the emergence of newspapers, the radio, and television facilitated the distribution of information among larger and larger shares of the population. At the same time, selection and filtering during the editorial process of media production may affect the formation of voters' opinions and change the way people vote. It appears that more information comes at the cost of a potential media-induced bias because scale economies in the provision of information imply a concentration of media outlets. Specifically, biases may arise from media actively supporting a certain political ideology (cf. DellaVigna and Kaplan 2007; Durante and Knight, 2011) or the media might concentrate on political issues of general interest and crowd out local topics since the media serve increasingly integrated markets (Snyder and Strömberg, 2010; Gentzkow, 2006).

The emergence of the Internet as the new mass medium of the $21^{\text {st }}$ century now changes the market of mass media substantially. Information can be distributed at high speed, low cost, and broad scope and as a result, there is egalitarian access to the production and the consumption of news (cf. Prat and Strömberg, 2011). The unanswered question is whether the possibility to avoid editorial filtering does indeed influence voting behavior. We might expect a more differentiated supply of information but we also see the editorial offices of existing media outlets setting up webpages that distribute news in real time at an even larger scale. Moreover, Internet access per se does not guarantee more information because the possibility to self-select information bears the risk of an ideological polarization or even a decrease in information if voters prefer entertainment over information. Unfortunately, little is yet known about the role of the Internet with the result that "some of the allegedly greater democracy in cyberspace is based more on hope and hype than on careful research” (Putnam, 2000, p.173).

This paper analyzes the effect of the new mass medium Internet on voting behavior. We combine rich data on local elections, state elections, and national elections in Germany at different points in time with unique telecommunication data that document the availability of broadband Internet access across roughly 12.000 German municipalities. Broadband Internet provides access rates of at least $384 \mathrm{Kbit} / \mathrm{s}$. At lower access rates, the information function of the Internet is severely limited thus not constituting a relevant alternative to traditional mass media. The structure of our data allows us to compare voting behavior before the Internet era 
prior to the year 2000 to voting behavior after the Internet era began in the year $2004 .{ }^{1}$ Based on this data, we analyze two potential effects of the Internet on voting behavior: (i) the effect of the Internet on voter turnout; (ii) the relative importance of the Internet for single parties, that is, established parties and small parties at the left and right fringes. In both cases, the effect of the Internet on voting behavior is not entirely clear a priori and the identification of a causal relation is additionally complicated by endogeneity concerns. Rolling out the infrastructure for high-speed Internet is quite costly what makes it efficient to exploit scale economies in densely populated areas. Accordingly, the mere correlation between Internet availability and voting behavior might just as well reflect selective migration to agglomerated areas. If, for instance, people in urban areas were more (less) interested in politics or political participation, OLS estimates would be upward (downward) biased. We resolve this endogeneity problem by exploiting exogenous variations in who has access to the Internet. ${ }^{2}$

The identification strategy builds on the incidence that the first generation of DSL broadband technology in Germany was entirely built on the preexisting voice telephony network which did not fully support DSL technology. ${ }^{3}$ We derive three plausibly exogenous sets of instruments from predetermined characteristics of the preexisting voice telephony network that affect the supply of fixed-line broadband Internet. The first is that the traditional public switched telephone network is based on copper wires. These wires were rolled out long before the Internet era with the goal to provide universal voice telephone service to all German households. For our purpose, the relevant part of the telephone network is the copper wires that connect households to a main distribution frame (MDF). As the exact distance did not affect the quality of voice telephone services, the layout of this last connection part was mostly determined by the availability of buildings to host the central office with the operators manually switching telephone calls. In contrast to telephone services, the capacity of the DSL technology does depend on the length of the copper wire between the household and the MDF. When surpassing a technologically determined threshold of 4.2 kilometers (2.61 miles), DSL technology is no longer feasible and parts of the copper wire need to be bypassed with fiber wire. This involves costly earthworks as wires are rolled out subsurface in Germany. As

\footnotetext{
${ }^{1}$ Broadband Internet infrastructure was initially rolled out in Germany between the years 2000 and 2004. Consequently, we discard this "rollout period” from our analysis.

2 This strategy is similar to other identification strategies that exploit exogenous variation in technological possibilities to determine the effects of comparable media on voting behavior and political participation. For instance, Strömberg (2004a) uses geological features that affect the quality of radio reception as instruments for the share of households with a radio and Olken (2009) exploits topographical differences that affect signal strength to identify the effect of exposure to television.

${ }^{3}$ Digital subscriber line (DSL) is the dominant Internet technology in Germany. DSL includes all technologies that employ the copper wires of a local telephone network to transmit data.
} 
a result, the probability of a municipality having access to broadband Internet decreases above this threshold. We exploit this kink at the threshold to determine a technical explanation for a systematically lower availability of DSL in municipalities surpassing the threshold.

A second distance related instrument exploits "wrongly" connected municipalities as source of exogenous variation in the availability of DSL. About 6\% of the municipalities in Germany were connected to an MDF at a distance larger than 4.2 kilometers despite the existence of a closer MDF at a distance below the threshold. The choice of "wrong” MDFs relates to the geographic layout of telephone access areas. Organizational considerations led the stateowned monopolistic operator of the telephone network (Deutsche Bundespost) to connect municipalities only to the one MDF within their telephone access area even though there was a closer MDF in adjacent telephone access areas. This procedure reflects that distance did not affect the quality of telephone services. Now that distance does play a role for the Internet transmission quality, it is often cheaper for the telecommunication carrier to connect a municipality to the closer MDF than replace the copper wire to the "wrong" MDF that actually serves the municipality. This leaves us with a technical explanation why some of the municipalities above the threshold are more likely to have DSL access.

Beyond these distance-related instruments, a third instrument exploits the variation from a technological mistake affecting the provision of broadband Internet till today. After the German reunification in 1990, there was a lack of telephone access lines in many parts of East Germany. ${ }^{4}$ The new infrastructure that closed this gap was built on the basis of a special type of fiber wires instead of copper wires. This new OPAL technology was expected to dominate the ICT future as it was suitable for voice-telephony services, ISDN services, and a limited amount of data transmission. However, the ongoing request for higher bandwidths soon overextended the OPAL capacities and instead DSL became the leading access technology for broadband Internet in Germany. This development was the misfortune of roughly $11 \%$ of the East German households because the fiber wires were not compatible with the copper cable based DSL technology. Large investments were necessary to reverse this mistake and as a result, many of these areas cannot access DSL until today. This provides an additional source of exogenous variation in DSL availability that is not based on geographical distance.

All sources of technical variation turn out to be highly relevant in our instrumental variable estimations and they show the expected signs. The results of the second stage voting behavior estimations suggest that an increase in DSL availability from 0 to 100 percent decreases voter

\footnotetext{
${ }^{4}$ Just before reunification, only about 10 percent of the East German households had telephone access.
} 
turnout by 1.9 to 2.5 percentage points. Given an average turnout of 64.4 percent, this translates into a reduction of 3.0 to 3.9 percent. Our findings further suggest that single parties cannot systematically benefit from the Internet as platform to increase their publicity. However, in some specifications, we do find a marginally significant but sizable effect on the vote share for extremist right wing parties suggesting that an increase in DSL availability from 0 to 100 percent reduces their vote share by 0.4 percentage points. Given their average vote share of 2.2 percent, this is, after all, a 20 percent lower vote share.

The magnitude of the Internet effect on voter turnout is comparable to the effect of the introduction of TV on voter turnout in the US reported in Gentzkow (2006). He estimates that the introduction of television in the 1940s and 1950s reduced voter turnout in congressional races by 2 percent. While the negative effect of TV on voter turnout is particularly pronounced in local elections our estimations suggest that the Internet effect on voter turnout is driven by non-local elections. We can further show that those municipalities that comply with our instruments experience a significantly stronger decrease in the circulation of national daily newspapers than in the circulation of local daily newspapers. This crowding out of national newspapers reflects the increasing popularity of online newspapers like the most popular German news portal spiegel-online. Online news portals provide constantly updated information on a wide range of political topics. On the downside, this information becomes increasingly superficial because the common practice to report what happens before the eyes leaves no time to collect background information. The decrease in in-depth coverage and information on broader issues is in line with the observed decrease in voter turnout in stateand national elections. At the same time, local newspapers faced less competition at the beginning of the Internet era because of their limit range and local focus. As a result, the Internet crowds out less local information and we find no indication of voter turnout in local elections being affected by broadband Internet access.

Robustness tests confirm the validity of our results. First, we consider the existence of timepersistent effects which explain systematic differences between municipalities with high DSL availability and municipalities with low DSL availability that are not related to the introduction of DSL. To test for this competing explanation, we exploit the time dimension of our data and shift the window of our analyses to elections before the emergence of broadband Internet, i.e. before 2000. In line with our arguments, we do not find any indication of differing voting behaviors between complier municipalities and control municipalities. In a second robustness check, we consider an alternative explanation for the observed effect of the Internet on voter turnout. Imagine that the Internet improved the economic conditions of 
municipalities with high DSL availability systematically. If better economic conditions which translate into higher wages and employment reduced voter turnout (Charles and Stephens Jr., 2011) this would provide an alternative explanation for the observed differences in voter turnout. To test this competing explanation, we perform comparable instrumental variable regressions with a municipality's unemployment rate as outcome variable. We find no significant effect of DSL availability on the unemployment rate suggesting that we indeed identify an information crowding-out effect of the Internet on voter turnout.

The remainder of the paper is organized as follows. Section 2 reviews the existing literature on the political economy of mass media and discusses the expected effect of the Internet on voting behavior. Section 3 introduces the data and shows the association between Internet availability and voting behavior in a multivariate framework. Section 4 advances our empirical strategy to a causal analysis and introduces our instrumental variable strategy. We present our baseline results and contest them with placebo regressions from the prebroadband-Internet era. We also explore the heterogeneity of the Internet effect on voting behavior. Section 5 sheds light on the mechanisms behind the Internet effect on voting behavior. Precisely, we explore whether the Internet crowds out daily newspapers and the effect of the Internet on local unemployment. Section 6 concludes.

\section{The Political Economy of Mass Media}

Media are the main source of information for voters about government policies and ideological positions of parties and politicians. Theoretical models that formally express this relationship suggest that more information is generally good for voters because it helps them monitor politicians more efficiently (cf. Besley and Prat, 2006; Strömberg, 2004b). This simple insight is reflected in freedom of information legislations that guarantee access to government information. However, the quality of information provided by the media may vary across political issues and across regions thus giving rise to different kinds of media bias. One obvious bias would arise from a situation where the broad range of mass media was strategically employed to manipulate the public opinion (cf. McMillan and Zoido, 2004). We usually observe this in rather totalitarian regimes. However, even in the absence of strategic manipulation, media can still exert a tendentious influence on the public opinion as they might strengthen voters' predispositions by pervasive selection and filtering (cf. Prat and Strömberg, 2011). The intense Media coverage of an issue can make people believe that this issue is important (agenda setting); people may evaluate politicians' decisions based on the issues 
covered in the media (priming); and the way an issue is characterized in news reports can have an influence on how it is understood by audiences (framing).

These different sources of biases seem especially feasible in the context of traditional mass media like newspapers, the radio or TV where editorial boards determine which topics are covered. For instance, DellaVigna and Kaplan (2007) analyze the impact of the introduction of Fox News in the United States on voting behavior between 1996 and 2000 and find that the entry of Fox News had a significant effect on the Presidential elections in 2000 with the Republican vote share increasing by 0.4 to 0.7 percentage points. Similarly, Enikolopov, Petrova, and Zhuravskaya (2011) analyze the expansion of the first private Russian TV channel (NTV) which supported the opposition in the 1999 parliamentary elections in Russia. Their estimations suggest that the presence of the independent TV channel decreased the aggregate vote for the government party by 2.5 percentage points while the combined vote for major opposition parties increased by 2.1 percentage points. Moreover, Prat and Strömberg (2006) analyze the introduction of a new commercial TV channel in Sweden as additional source of political information. Using survey data from the same respondents in two consecutive general elections before and after the entry of the commercial channel in 1990, they find significant effects on voters’ political knowledge and voter turnout.

For the case of information provided by newspapers, Snyder and Strömberg (2010) find that a poor fit between newspaper markets and political districts reduces press coverage significantly. Increasing the congruence of newspaper markets and political districts from 0 to 1 is associated with 170 more articles written about the district's congressman. The authors then employ this variation in press coverage to infer on voter information and its effect on politicians' actions and policies. They find that voters living in areas with less coverage of their U.S. House representative are less likely to recall their representative's name and they are less able to describe and rate her. This lack of information (and accountability) leads to significantly lower amounts of federal funds flowing into less congruent districts. ${ }^{5}$ Newspaper coverage does also influence voting behavior. Gentzkow et al. (2011) analyze the effect of increased newspaper coverage in a panel of all U.S. newspapers published in English language that existed between 1869 and 2004. They estimate that one extra newspaper is associated with a 0.3 percent increase in voter turnout. These effects appear to be stronger in the period before 1929, i.e. before the rise of radio and TV.

\footnotetext{
${ }^{5} \mathrm{~A}$ similar relationship between newspaper penetration and government spending is also reported by Besley and Burgess (2002) for the case of India. Bruns and Himmler (2011) show for the case of Norway that the circulation of local newspapers has a positive effect on local government efficiency.
} 
Studies on the effect of the introduction of radio and television on political participation again suggest an effect of mass media on voting behavior. Strömberg (2004a) analyses the introduction of the radio in the United States in the period from 1920 to 1940 in the context of an unemployment relief program that was implemented during the diffusion period of the radio between 1933 and 1935. He estimates that an increase in the share of households owning a radio from 0 to 100 percent increases the voter turnout by 7 percentage points in this period. At the same time, regions with higher radio reception received higher funds from the unemployment relief program. This supports the idea that voters' access to mass media influences voter turnout and government policies.

Gentzkow (2006) studies the effect of the introduction of television in the U.S. on voter turnout in an attempt to explain the observed decrease of voter participation in the period from 1940 to 1970 . Using variation across regions in the timing of the introduction of this mass medium, he shows that the introduction of television had a negative effect on voter participation. The estimations suggest that the introduction of television in the 1940s and 1950s reduced the turnout in congressional races (without simultaneous presidential elections) by two percentage points. Gentzkow argues that the effect is caused by TV crowding out media with more extensive coverage on political issues thus reducing the electorates' knowledgeability of political issues. In line with this, the introduction of television in a region was accompanied by a strong decrease of the diffusion of newspapers and radio in this region. By contrast, Oberholzer-Gee and Waldfogel (2009) find that the introduction of local Spanish-language television in US metropolitan areas improved the availability of information and eventually increased voter turnout among Hispanics in the metro area by 5 to 10 percentage points.

This paper focuses on the new mass medium of the $21^{\text {st }}$ century, the Internet, and the effect of its introduction on voting behavior. Previous research on the effect of mass media on voting behavior suggests that the Internet may similarly crowd out traditional media thus affecting voter turnout and election outcomes. In line with this concern, Liebowitz and Zentner (2011) show that the Internet has a small crowding out effect on TV. Whether and to which extent the Internet crowds out newspapers has not been analyzed so far. This paper will also provide evidence on this. The main reason why the Internet may affect voting behavior is its potential to provide direct and cheap access to the consumption and production of information without editorial filtering. However, the absence of editorial filtering may also come at some costs. If people now filter news by themselves and only consume the information and topics they want to hear and read about this might very well cause ideological lock-ins (Sunstein, 2001). While 
the consumption of traditional media such as newspapers, radio or TV still urges people to encounter diverse viewpoints and to be exposed to new topics and ideas, self-selected news consumption according to prior beliefs bears the risk of segregation thus leading to ideological polarization. ${ }^{6}$ Accordingly, the introduction and diffusion of the Internet may increase or decrease the range of news and opinions people are exposed to. We thus hypothesize that the Internet-like other mass media-does affect voting behavior, but we do not have a priori assumptions about the direction of this effect.

In an attempt to get a better understanding of the potential ideological bias caused by a selective use of the Internet, Gentzkow and Shapiro (2010b) analyze the ideological segregation of individuals' online news consumption. Their data for the U.S. suggests that segregation on the Internet is low, however higher than in most traditional media, and significantly lower than segregation in face-to-face interactions. Online news consumption is mostly concentrated on a small number of relatively centrist outlets whereas ideologically extreme outlets such as political blogs or activist sites only account for a very small share of online news consumption. This paper takes the initial studies on the effect of the Internet on political participation and political opinions one step further: It analyzes how the introduction of the Internet and the possibility to consume online news affects actual voting behavior and assesses the causality of this relationship.

\section{High-speed Internet Availability and Voting Behavior}

\subsection{High-speed Internet availability in German municipalities}

Figure 1 shows the development of broadband subscriptions in Germany from 2001 to 2010. Broadband Internet connections via DSL technology were introduced to the market for private households in July 1999 by the incumbent network provider Deutsche Telekom. By the end of this year, 100,000 subscriptions existed (Bundesnetzagentur, 2000). The increasing importance of the Internet pushed the success of DSL and led Deutsche Telekom and its competitors to further develop the broadband infrastructure. As DSL networks where set up in larger cities, 8\% of the population could access DSL in 2001 (Bundesnetzagentur, 2001). Out of 1.9 million broadband subscriptions registered in the year 2001, only 30,000 relayed on another technology than DSL. This underlines the role of DSL as dominant technology for broadband Internet connections which persisted over the following years. Only in 2007,

\footnotetext{
${ }^{6}$ Campante and Hojman (2010) find that the introduction of radio and TV contributed to a reduction in the ideological polarization of the United States in the mid- $20^{\text {th }}$ century.
} 
broadband subscriptions via other technologies (mainly via the cable TV network) reached more than 5\% market share. While this share is increasing since then, DSL is by far the most commonly used technology to access the Internet in Germany.

$<<$ Figure 1 about here $>>$

In this analysis, we employ data on high-speed Internet availability on the municipality-level. These data are taken from the German broadband atlas (Breitbandatlas Deutschland), an annual survey on broadband Internet availability conducted by the German Ministry of Economics and Technology since the year 2005. Network providers self-report the geographic areas they cover with their networks. This information is combined in a comprehensive dataset documenting the percentage of households that can access DSL across more than 12,000 German municipalities. ${ }^{7}$ The high geographical resolution of our data becomes obvious when considering that the average German municipality corresponds to a circle of radius $3.1 \mathrm{~km}$ (1.9 miles). Figure 2 shows histograms of DSL availability across German municipalities for the years 2005 to 2008 which is the time span covered in our analyses. Average DSL availability increased from 67 percent of the households in 2005 to 85 percent of the households in 2008. Furthermore, the share of so called white spots, this is municipalities with no DSL availability, decreased over this time span from more than 5 percent in 2005 to about 2 percent in 2008.

\section{$<<$ Figure 2 about here $>>$}

We now turn to the question for what purposes individuals use the Internet. We are interested in the information function of the Internet thus implicitly assuming that individuals use the Internet to some extent to access news. To further assess this assumption, we employ a study by Arbeitsgemeinschaft Media-Analyse that asked nearly 19,000 individuals in Germany for which purpose they use the Internet (cf. Table 1). The survey was conducted in 2007 and allowed multiple answers. The most frequent answer was "Information Search" (94.6 \%) closely followed by "Email” (89.4\%), and "News" (71.7\%). By contrast, "Entertainment” has been chosen by only $48.8 \%$ of the interviewees. Along with an Internet usage rate of 60.2 percent of the German population in 2007 (Initiative D21, 2010), these figures suggest that the Internet does have an information function and with its various news sites and information

\footnotetext{
${ }^{7}$ Note for the interpretation of all subsequent results that the municipality-level DSL rate is measured as DSL availability, i.e. the percentage of households in a municipality for which a DSL subscription is technically available. However, it is not the pure availability of DSL but its use that will affect the outcome variables on voting behavior. We thus estimate the effect of DSL availability on the outcome variable and not the effect of DSL use. Technically, we estimate the intention to treat effect and not the treatment effect, a procedure that does overcome endogeneity problems when assessing the effect of DSL use on voting behavior.
} 
channels, the Internet has become an important player in the mass media market. It is however worth noting that a bandwidth of at least $384 \mathrm{Kbit} / \mathrm{s}$ is the minimum requirement to use the Internet to access online news properly. We simulated, for example, the time to access the webpage Spiegel Online, one of the most viewed news sites in Germany, at different bandwidths. The main elements of this site loaded within 15 seconds at a DSL connection of $384 \mathrm{Kbit} / \mathrm{s}$. With a dial-up Internet connection of 56k, loading the same site took more than one minute.

$<<$ Table 1 about here $>>$

\subsection{Election data}

We measure the effect of the Internet on two aspects of voting behavior: (i) voter turnout and (ii) the vote share of single parties, including established parties as well as radical parties. We observe these outcome variables at the municipality-level for elections at the three main levels of governance in Germany, i.e. elections for the Federal Parliament (Bundestagswahlen), elections for the State Parliaments (Landtagswahlen), and elections for the municipal- or city councils (Gemeinderatswahlen or Stadtratswahlen). ${ }^{8}$ The data are obtained from the statistical offices of the 16 German states. ${ }^{9}$ For each election type, we consider three elections-two elections from the time before the year 2000, i.e., before the DSL infrastructure roll-out, and one election from the year 2004, i.e., a time when DSL diffusion has surpassed a critical mass of users. We exploit information from elections before the year 2000 in value-added models and placebo regressions. Data from different municipalities are collapsed if municipalities merged during the period of our analysis. Our final dataset is a balanced panel of election data that draws a precise picture of political preferences and their changes across roughly 12,000 German municipalities over the last 20 years. Table 2 summarizes the timing of the three types of elections selected for our analysis.

\footnotetext{
${ }^{8}$ Note that many German cities do not belong to a county (kreisfreie Staedte). Those municipalities elect their own city council, but they do not participate in elections for a county council. Hence we discard elections for the county councils that always take place simultaneously to the elections for the municipality councils from our analysis.

${ }^{9}$ Namely these are the Statistisches Amt fuer Hamburg und Schleswig-Holstein (Hamburg and SchleswigHolstein), Statistisches Landesamt Sachsen-Anhalt (Saxony-Anhalt), Amt fuer Statistik Berlin-Brandenburg (Berlin and Brandenburg), Bayerisches Landesamt fuer Statistik und Datenverarbeitung (Bavaria), Statistisches Landesamt Baden-Wuerttemberg (Baden-Wuerttemberg), Hessisches Statistisches Landesamt (Hesse), Statistisches Landesamt Rheinland-Pfalz (Rhineland-Palatinate), Statistisches Amt Saarland (Saarland), Landesbetrieb fuer Statistik und Kommunikationstechnologie Niedersachsen (Lower Saxony), Landesbetrieb Information und Technik Nordrhein-Westfalen (North Rhine-Westphalia), Statistisches Landesamt Bremen (Bremen), Statistisches Landesamt des Freistaates Sachsen (Saxony), Statistisches Amt MecklenburgVorpommern (Mecklenburg-Western Pomerania) and Thueringer Landesamt fuer Statistik (Thuringia).
} 
In the absence of irregular early elections, Federal elections take place every four years. The legislative periods of state parliaments vary between 4 and 5 years. Federal parliaments and state parliaments are both legislative bodies that elect and control the respective government. For all German parliaments, the electoral system mainly rests on the principle of proportionality, i.e. a party's vote share translates into its share of seats in the elected parliament. Voters deliberately choose their preferred parties and this decision expresses their preference for a party's political profile. Accordingly, the proportional vote is an appropriate approximation of the policy-orientation within a specific region. ${ }^{10}$

Elections for the municipal- or city councils are held every 4 to 6 years. Those councils do not have legislative authority but control and advice authorities at the corresponding regional level. Nevertheless, councils influence local policy outcomes, since their resolutions are binding for the local authorities, thus determining the overall goals and measures of political action on the local level. The actual election systems for the municipal- or city councils vary significantly between states, mainly with regard to the way mandates are distributed. But nearly all municipalities still distribute the seats in the respective councils by proportional rule. The few remaining municipalities who apply majority rule as major principle to their council elections are excluded from our analysis. We further exclude the three city-states Hamburg, Bremen, and Berlin from our analysis. Elections on the sub-national level are subject to the special institutional setup in these small city states and a comparison with subnational elections in the other 13 states would likely be biased.

The vote shares of single parties are calculated as share of the overall votes in an election and municipality. Established parties are the conservative parties CDU and $\mathrm{CSU}^{11}$, the social democratic party SPD, the liberal party FDP and the ecologist green party GRUENE. These parties are active on all levels of governance, have sub-organizations in all German states, always participate in all German elections, regularly gain seats in the German parliaments, and usually provide the federal government and state governments respectively. All five parties have been active for at least 30 years and arguably dominate the political life in Germany during the time window of our analysis.

\footnotetext{
${ }^{10}$ Note that federal elections and many state elections also contain an element of majority vote as voters can use a second ballot to elect their districts representative. With this ballot, voters decide on individual nominees who are mostly party delegates. If they win a majority of votes in their election district, they are elected for parliament. As the election of individual candidates does not affect the distribution of seats in parliaments, the proportional vote is the decisive vote in all German federal and state elections. Therefore, we restrict our outcome to the proportional vote ballots.

${ }^{11}$ With the CSU being the Bavarian branch of the CDU.
} 
The group of not established parties consists of numerous organizations of different sizes and ideological backgrounds that only occasionally gain seats in state parliaments or the federal parliament. ${ }^{12}$ Within this group, we are especially interested in the vote shares of parties from the extreme right-wing and the extreme left-wing of the political spectrum. The most prominent among the extreme right wing parties' include the radical nationalist parties NPD, DVU and REP. At the other end of the political spectrum, we look at vote shares of various Marxist and Leninist parties, first and foremost the socialist party LINKE and its predecessors PDS and WASG. ${ }^{13}$

$<<$ Table 3 about here $>>$

Table 3 shows summary statistics on different election outcomes. From the year 2004 on, voter turnout varied between 60 percent and 73 percent depending on the type of elections. The vote share of established parties reached more than 80 percent in supra-regional elections. In local elections, established parties only reached a vote share of about 55 percent. The vote share of extreme right wing parties was about 3 percent in supra-regional elections and close to zero in local elections. Note that, in general, a single party must reach a vote share of 5 percent in supra-regional elections to get a seat in the respective parliament. Extreme left wing parties reached vote shares of up to 10 percent which is mainly driven by the socialist party LINKE and its predecessors PDS and WASG.

\subsection{The association between high-speed Internet availability and voting behavior}

Table 4 shows the results of simple multivariate regressions of DSL availability (measured as share of households having access to broadband Internet in a municipality) on different measures of voting outcome. As we concentrate on elections after the DSL infrastructure rollout, we consider election outcomes from the year 2004 on and add year of election dummies. ${ }^{14}$ In our main specification, we pool the three types of elections (municipality, state, and national) and add election type dummies as controls. All regressions further condition on a set of municipality-level control variables including surface, population, female population

\footnotetext{
${ }^{12}$ Nevertheless they might play some role when it comes to city or municipality councils.

${ }^{13}$ One might argue that the socialist party LINKE is also an "established" party. LINKE is a merger of the PDS, i.e. the successor of the socialist unity party formerly ruling the German Democratic Republic and thus mostly active in East Germany, and some leftist parties and factions rooted in West Germany. While LINKE nowadays manages to gain a fair amount of votes all across Germany, during our period of analysis it was mainly an East German party. We thus choose to label it as small party instead of incumbent party. Changing this does not affect our results.

${ }^{14}$ DSL availability on the municipality-level is not available for the year 2004. We thus merge election outcomes from the year 2004 with DSL availability in the year 2005. For all other years, we can merge our election data with our data on DSL availability on a year-to-year basis.
} 
share, age structure of the population, and unemployment rate. To guarantee that we only compare municipalities that are most similar with the exception of DSL availability, we finally add a full set of county dummies. The average German county contains about 27 municipalities and represents a quite homogenous regional entity. Our standard errors are clustered on the municipality level because voting outcomes in the three types of election might be correlated within municipalities.

$$
<<\text { Table } 4 \text { here }>>
$$

Conditional on our municipality-level control variables, election type dummies, year of election dummies, and county dummies, we find a significantly negative association between DSL availability in a municipality and voter turnout (Column 1); a significantly positive association between DSL availability and the vote share of established parties (Column 3); and a significantly positive association between DSL availability and the vote share of extreme right-wing parties (Column 7). We find no significant association between DSL availability in a municipality and the vote share of left wing parties (Column 5).

We do not interpret these results as causal effect of DSL availability on voting outcomes since there might be unobserved municipality characteristics that are correlated with both the DSL availability and voting outcomes. Such a bias would arise from a selection of individuals into certain locations. Let us assume that open-minded and highly educated individuals who are also interested in political issues prefer to move to dense areas rich of amenities and job opportunities. At the same time, dense areas face cost advantages in the provision of broadband infrastructure because of scale effects in the roll-out process. Combined with a large number of broadband Internet subscriptions in dense areas-presumably from young and highly-educated individuals_-profit-oriented telecommunication carriers started rolling out broadband infrastructure in dense areas. As result our OLS estimates should be upward biased. Of course, one can think of many other stories why OLS estimates might tell us little about the true underlying causal relationship between broadband Internet access and voting behavior.

To overcome estimation biases that result from unobserved time persistent factors that influenced past election outcomes, still influence contemporaneous election outcomes, and are correlated with DSL roll-out across municipalities, we exploit the time dimension of our data and include the respective voting outcomes from the years before the introduction of DSL in 2000. This procedure is often referred to as value-added model. It is especially valuable in the context of German election outcomes since norms and values that likely influence election 
outcomes are highly persistent over time and on a small geographic scale (Voigtlaender and Voth, 2012).

The results of the value-added models are shown in Table 4. We still find a significant negative association between DSL availability and voter turnout (Column 2) and a positive association between DSL availability and the vote share of established parties (Column 4). The association between DSL availability and the vote share of extreme left-wing parties becomes positive (Column 6); the association between DSL availability and the vote share for extreme right-wing parties becomes significantly negative (Column 8). While this step should control for all time persistent factors that might bias our results, we still worry about biases from time varying factors that simultaneously came up with the DSL technology and that are correlated with voting outcomes. To overcome this concern, we now turn to instrumental variable estimations where we exploit regional and technological peculiarities of the preexisting voice telephony network that hinder the roll-out of fixed-line broadband infrastructure for high-speed Internet.

\section{Assessing Causality}

\subsection{Technical foundations of DSL infrastructure}

We develop our instrumental variables from regional and technological peculiarities of the traditional public switched telephone network in Germany which affect certain municipalities’ possibilities to access broadband Internet. The voice telephony network was rolled out at a time when considerations of its suitability for DSL technology were not a concern. As early as 1936, we observe 6,647 local telephone networks with about 3.4 million connections and the network was further developed to its current layout from the 1950s on. This allows us to identify a group of municipalities that got worse initial conditions to access DLS technology at a time when DSL was not yet thought of. In the following, we will explain the technological peculiarities underlying our instrumental variable estimations in more detail.

The early generations of DSL technology in Germany completely rely on the copper wires between the household and the main distribution frame (MDF)-the so called 'last mile' of the traditional public switched telephone network (cf. Figure 3 for a graphical illustration of the telephone network structure). Employing the existing wires is a significant cost advantage because all wires are rolled out subsurface in Germany. The public switched telephone network was rolled out at a time when the provision of telephone services was a state 
monopoly with the declared goal to provide universal telephone service to all German households. While dense municipalities always have at least one own MDF, more rural municipalities typically share an MDF. The length of the copper wires was irrelevant for the quality of the telephone services and accordingly, the choice of MDF locations in more rural areas was determined by restrictions like the availability of buildings to host an MDF. However, in a DSL access network distance does play a crucial role because the maximum bandwidth depends on the length of the copper wire between the household and the MDF. When surpassing a threshold of about 4,200 meters (2.6 miles), DSL technology is no more feasible and one has to replace parts of the copper wire by fiber wire which involves costly earthworks that increase with the length of the bypass.

$<<$ Figure 3 and 4 here $>>$

Using GIS, we calculate the geographic distance from the geographic centroids of all municipalities to the MDF that serves the municipality. There are more than 8,000 MDFs in Germany which underlines the 'micro-geographic' structure of our data (cf. Figure 4). Figure 5 plots the DSL rate of a municipality against its distance to the actual MDF. The plot shows all municipalities around the critical threshold of 4,200 meters (2.6 miles). For clarity, the figure plots the average DSL availability of municipalities in bins of 100 meters (0.06 miles) as dots while the fitted lines depicting the DSL share (conditional on distance to the MDF) are calculated on the basis of all single observations. The figure clearly shows the kink in the DSL share at the threshold of 4,200 meters (2.6 miles). Municipalities with distances below 4,200 meters all have DSL shares between 70 to $80 \%$ (red line). At distances above the critical threshold DSL availably begins to decrease sharply (blue line).

\section{$<<$ Figure 5 here $>>$}

A second source of technical variation comes from some $6 \%$ of the municipalities with a distance to their actual MDF that is greater than 4,200 meters (2.6 miles) where a closer MDF exists at a distance below the threshold of 4,200 meters (2.6 miles). This peculiarity is the result of the geographic layout of the telephone access areas that were designed when distance was irrelevant (cf. Figure 6). At that time, organizational considerations determined the allocation of municipalities within certain telephone access areas. The assignment to a certain telephone access area tied the municipality to a particular MDF which, in some cases, was further away than a neighboring telephone access area's MDF. In such a situation it is now often cheaper for the telecommunication carrier to provide DSL to a municipality via the closer MDF than via the "wrong” MDF the municipality is actually connected to. Still, both 
procedures imply costly earthworks to roll-out new wires. We construct a dummy variable that equals unity for municipalities that are actually connected to a "wrong" MDF at a distance of more than 4,200 meters (2.6 miles) which could be connected to another MDF at a distance below 4,200 meters (2.6 miles). We expect this dummy variable to have a significant positive impact on DSL availability in the municipality.

$<<$ Figure 6 about here $>>$

The third source of technical variation is independent of distance. After the German reunification in 1990, there was a huge lack of telephone access lines in many parts of East Germany. To close this lack, telephony infrastructure was rolled out which was built on the basis of a special type of fiber wires, the so called OPAL technology, instead of the traditionally used copper wires. In the early 1990s, this technology was regarded to be the state-of-the-art technology that would dominate the ICT future. It is suited for voicetelephony services, ISDN services, and a limited amount of data transmission. OPAL technology was eventually rolled out in 213 East German areas (cf. Figure 7). But then things changed dramatically: The world saw the Internet revolution taking over with the Internet becoming a mass phenomenon and services on the Internet demanding higher and higher bandwidths. For reasons described above, DSL technologies became the leading access technologies for broadband Internet in Germany. This was, however, the misfortune for the thought-to-be-high-tech OPAL areas. The reason for this is that OPAL technology is simply not compatible with DSL technologies. In order to still provide broadband Internet to OPAL areas, two very costly alternatives were feasible. One could either replace the OPAL wires of the access network by copper wires or, what is even more expensive; install new hardware and software at the networks' nodes. We construct a dummy that equals unity for municipalities being situated in a (former) East German OPAL access area. We expect this dummy to have a significant negative impact on DSL availability.

\section{$<<$ Figure 7 about here $>>$}

Table 5 shows the results of a multivariate regression of DSL availability in a municipality in years of elections on the variables that are technically derived from the characteristics of the pre-existing voice telephony network. These variables include the distance to the actual MDF, a threshold dummy for distances above 4,200 meters (2.6 miles), the interaction between distance and the threshold dummy, a dummy for municipalities which are actually connected to a "wrong” MDF, a dummy for municipalities that are actually connected to a 'wrong' MDF with another MDF at a distance below 4,200 meters (2.6 miles), and an OPAL dummy. 
The results clearly confirm our technical predictions. Distance turns out to be irrelevant for DSL availability in a municipality below the critical threshold of 4,200 meters (2.6 miles). At the threshold, DSL availability drops by 3.1 percentage points. Above this threshold the DSL share decreases by 5.9 percentages points with every kilometer ( 0.6 miles) the municipality is farther away from the MDF. Not being connected to the closest MDF only shows a small positive effect of 2.3 percentage points. However, for municipalities that are actually connected to an MDF farther away than 4.2 kilometers (2.6 miles) but for which another MDF is closer by the DSL share additionally increases by 8.4 percentage points reflecting the possibility to redirect DSL access to the closer MDF. Finally, the DSL share of municipalities located in OPAL areas is 8.0 percentage points lower.

\subsection{The causal effect of high-speed Internet availability on voting behavior}

We now turn to IV estimations that exploit the regional and technical features of the preexisting voice telephony network to identify an arguably causal effect of high-speed Internet availability on voting behavior. We restrict our analysis to municipalities without an own MDF because our distance-related instruments are especially valid if we assume that the choice where to locate an MDF of the voice telephony network was as-good-as random. This is obviously not true for urban municipalities which all have at least one own MDF. However, more rural municipalities with a lower population density typically shared an MDF. Variation in DSL availability among the rural municipalities without an own MDF results from the fact that decades after the roll-out of the voice telephony network some of the municipalities were lucky to be closer than 4,200 meter (2.6 miles) to the next MDF while others were unlucky and more than 4,200 meters (2.6 miles) away. Concentrating on the more than 6,600 rural municipalities without an own MDF is a conservative approach that reduces the probability of unobserved heterogeneity between these municipalities. Within this subset, we compare municipalities within a county which had a lucky draw to those with an unlucky draw.

The regression results for the subsample of municipalities without an own MDF are shown in Table 6. Each cell shows the DSL availability coefficient from a separate regression. As a starting point, column 1 shows the value-added results for our sample. The results are comparable to those for the full sample shown in Table 4. Again, we pool outcomes of elections after 2004 at three main levels of governance in Germany, i.e. elections for the Federal Parliament (Bundestagswahlen), elections for the State Parliaments 
(Landtagswahlen), and elections for the municipal- or city councils (Gemeinderatswahlen or Stadtratswahlen). All regressions include controls for contemporaneous municipality characteristics (surface, population, female population share, age structure of the population, and unemployment rate), pre-DSL-infrastructure roll-out election outcomes, election type dummies, county dummies, and year dummies. We cluster our standard errors at the municipality level.

$$
<<\text { Table } 6 \text { here }>>
$$

In all IV specifications, the F-tests of excluded instruments range around 67 thus underlining the high relevance of our instruments. Our IV results clearly show a negative effect of DSL availability on voter turnout. An increase in DSL availability from 0 to 100 percent is estimated to have decreased voter turnout by 1.9 percentage points. We further find that DSL availability does not systematically benefit single parties. When looking at vote shares, the DSL availability coefficient is generally not significantly different from zero. The only exception is the regression on the vote share of extreme right wing parties where the DSL availability coefficient is marginally significantly different from zero and negative. Accordingly, an increase in DSL availability from 0 to 100 percent decreases the vote share by 0.4 percentage points. Given an average vote share of 2.2 percent, this effect translates into a sizeable decrease of 20 percent.

In a robustness test, we change all our distance-related measures and calculate the distance between the MDF and a municipality's population center instead of its geographic centroid. Doing so accounts for the possibility of an uneven population distribution across the municipality which would violate the assumption that the geographic centroid approximates a household's average distance to the next MDF. We used Google Earth and the Corine Land Cover database to determine each municipality's population center. ${ }^{15}$ The results are shown in Column 3. In general, the DSL availability coefficients change only slightly indicating that the geographic centroid approximates a municipality’s population center quite well. Based on this alternative distance measure, an increase in DSL availability from 0 to 100 percent is now estimated to have decreased voter turnout by 2.5 percentage points. When looking at vote shares, the DSL effect on the vote share of extreme right-winged parties as well as incumbent and left-winged parties is not significantly different from zero in all specifications.

\footnotetext{
${ }^{15}$ Note that we only calculate the contemporaneous population centers and thus rely on the assumption that the population centers did not change over our period of analysis.
} 
One might argue that our complier municipalities' voting outcomes already differed from the other municipalities before the introduction of DSL. Although we already control for pre-DSL infrastructure roll-out election outcomes, we additionally run placebo regressions. Here, we regress pre-DSL infrastructure voting outcomes from the years 1995 to 1999 on instrumented DSL availability. The placebo specification is also a value-added specification that includes election outcomes from the years 1990 to 1994 as controls. In this earlier period, (instrumented) DSL availability cannot affect voting behavior since the technology did not yet exist. Hence measuring significant placebo coefficients would be an indication for an omitted variables bias in our IV regressions. Again, all placebo regressions include contemporaneous municipality characteristics from the pre-roll-out period (surface, population, female population share, age structure of the population, and unemployment rate), election type dummies, county dummies, and year dummies. We also cluster our standard errors at the municipality level. The results are shown in Column 4 of Table 5 for the distance-related instruments calculated from the geographic centroids of the municipalities. All coefficients are not significantly different from zero and most point estimates are also close to zero. ${ }^{16}$ This provides confidence that we indeed identify a causal effect of high-speed Internet availability on voting outcomes which does not simply reflect persistent differences between municipalities.

\section{$<<$ Table 7 about here $>>$}

We also tested the Internet effect on electoral volatility within the group of established parties to account for potential shifts between parties due to better Internet availability. The underlying argument is that media coverage determines voters' possibilities to hold politicians accountable (cf. Snyder and Stroemberg; 2010). While the process of screening and filtering in the traditional media might affect the quality of information, we argue that the Internet provides a way to distribute unbiased information as news do not have to pass editorial departments. ${ }^{17}$ To the extent that the Internet supports a more differentiated supply of information and that individuals use this information to monitor politicians more effectively, increased accountability may be reflected in a higher turbulence in parties' vote shares.

\footnotetext{
${ }^{16}$ Note that the lower number of observations in our placebo estimations is due to missing observations for municipality and state elections in the state Schleswig-Holstein (see Table 2). To test whether the exclusion of these observations biases our results, we re-ran the value added and instrumental variable regressions without these two elections. It does not affect our results. Results are available from the authors on request.

${ }^{17}$ For instance, Puglisi and Snyder (2011) suggestively ask how much negative news a newspaper will carry about ideologically close politicians. Using data on US newspapers, they find that papers with a Republican tendency tend to write more about scandals that involve Democrats and vice versa. Gentzkow and Shapiro (2010a) further show that biases in the US newspaper market are mostly driven by their audiences' ideological leanings.
} 
However, our estimations do not provide any indication for an increased volatility within the group of established parties. The results are available from the authors on request.

In a final step, we now turn to the heterogeneity of the effect of DSL availability on voting outcomes across election types, i.e., federal - , state -, and municipality elections. ${ }^{18}$ Table 7 shows the effects of DSL availability on our voting outcomes of interest across the three election types. These subsample analyzes suggest that the effect of the Internet on voter turnout is driven by supra-regional elections at the federal and state level. In the next section, we will rationalize this finding by a crowding out of national newspapers but not local newspapers.

\section{Mechanisms}

\subsection{Crowding-out of Newspapers}

A possible explanation for the negative effect of the Internet on voter turnout is that the Internet carries less or other information than the media that it crowds out. Recent research on whether the Internet is just a substitute for TV suggests that TV is so far not affected by the emergence of the Internet (Liebowitz and Zentner, 2011). We can reproduce this finding for Germany in simple multivariate regressions on the basis of representative individual-level time use data collected as part of the German Socioeconomic Panel (SOEP). Regressing the respondents' intensity of TV consumption on their intensity of Internet consumption conditional on a large set of socio-economic background variables we find a positive and statistically significant association between TV and Internet consumption. The analysis is performed for the year 2008 on the basis of data from about 18,500 respondents. Detailed results are available from the authors on request.

Next we turn to newspapers and test whether the emergence of the Internet exerts a crowding out effect that might explain the negative effect on voter turnout. Comparable to Gentzkow (2006) who shows that TV crowds out newspapers, the Internet might crowd out daily newspapers. Given that we only find negative effects of the Internet on voter turnout in supraregional elections, the Internet may crowd out national newspapers but not local newspapers. Local newspapers are the primary source of information about local topics and local politicians' efficiency (cf. Bruns and Himmler 2011). Given the regional restriction of their

\footnotetext{
${ }^{18}$ We also ran regressions for East and West Germany separately. The negative effect on voter turnout is in absolute terms significantly larger in the West sample than in the East sample. Overall, the coefficients are more precisely estimated in the West sample. The results are available from the authors upon request.
} 
readership, local newspapers likely face less competition from online news because of limited returns to scale. Local newspapers being unaffected by the Internet would also be in line with findings on a crowding out of social capital by TV or the Internet. Local newspapers are often seen as a measure for local social capital or the "civicness" of the local population (Putnam 1993). Olken (2009) shows that TV crowds out local social capital while the Internet does not seem to crowd out social capital measured over several dimensions (Bauernschuster et al. 2011).

To test whether the Internet crowds out national newspapers but not local newspapers, we use municipality-level information about the circulation of all German daily national and local newspapers from 2000 to 2010. Data are provided every two years by the Informationsgemeinschaft zur Feststellung der Verbreitung von Werbeträgern e.V. (IVW). On average, 50 percent of the households in the municipalities without an own MDF read a daily local newspaper at the beginning of the Internet period in 2004 and 7.4 percent read a daily national newspaper. By the end of our observation period in 2008, these numbers decreased to an average of 46 percent of the households reading a daily local newspaper and 6.8 percent reading a daily national newspaper. Figure 8 shows the average number of daily national and local newspapers across the subsample of municipalities without an own MDF over the whole period 2000 to 2010. The figure clearly shows that the circulation of both national and local daily newspapers decreases over time. However, at the beginning of the Internet era, the relative decrease of national newspapers becomes relatively steeper than the decrease of local newspapers. $^{19}$

\section{$<<$ Figure 8 about here $>>$}

To directly relate the relative decline of national and local newspapers to the availability of broadband Internet, we run a three equation seemingly unrelated regression model. The first equation relates the growth rate of local newspapers per household in a municipality from 2004 to 2006 (2008 or 2010 respectively) to the DSL availability at the beginning of the period. The second equation repeats these estimations for national newspapers. Finally, the third equation relates DSL availability in 2005 to the full set of instruments. We also condition these estimations on the same set of municipality characteristics used before and on the log of the initial number of local newspapers per household in 2004. The results of our regressions are shown in Table 8. Across all timespans and specifications, results point to the

\footnotetext{
${ }^{19}$ Note in this context that only a small part of the sharp decline in national printed newspapers can be explained by subscriptions for e-paper versions of national daily newspapers. In 2005, about 27,000 e-papers were sold Germany-wide. This number only increased to about 57,000 sold e-papers in 2010.
} 
same direction. In municipalities with high DSL availability, the decline of national daily newspaper circulation is accelerated while the generally flatter decline of local daily newspaper circulation even decelerates. We interpret this finding as one explanation for the observed negative effect of DSL availability on voter turnout in supra-regional elections but not in local elections.

$<<$ Table 8 about here $>>$

\subsection{Internet, Unemployment and voting Behavior}

Charles and Stephens Jr. (2011) argue that activities that provide political information are substitutive to labor market activity. As a consequence, increased labor market activity should go in hand with lower voter turnout. The Internet might thus affect voter turnout through two channels: (i) through the information channel as discussed above and (ii) through an economic channel. If the Internet increased economic activity and thus labor market participation we would expect that voter turnout decreases. Indeed, Czernich et al. (2011) show important economic growth effects of broadband infrastructure in a cross-country analysis. Crossregional evidence for the U.S. however suggests that the local economic benefits of broadband expansion for a single location are limited (Kolko, 2012). Taking these two results together, one might come to the conclusion that the Internet does have positive effects on macroeconomic growth which result from increased transparency, more competition, or ICTbased organizational innovations within firms; however, the Internet did not change the spatial distribution of economic activity within a country.

$<<$ Table 9 about here $>>$

To test whether this alternative and indirect mechanism is at work, we re-run our crossmunicipality analyses with the unemployment rate as alternative outcome variable. We consider the unemployment rate to be a comprehensive measure of the overall economic activity in a municipality. The results are shown in Table 9. Once we instrument Internet availability and thus come to a causal interpretation of our results, we do not find any indication of this alternative economic mechanism. Differences in the availability of broadband Internet do not cause any significant differences in the local unemployment rates. This finding additional supports our strategy and conclusion that we identify an information (crowding-out) effect of the Internet on voter turnout. 


\section{Conclusions}

This paper analyses the effect of the Internet on voting behavior. Research on the introduction of the equally influential mass media radio and TV shows that increased media coverage provides more information for voters. However, while more information is generally good for voters because it promotes the accountability of politicians, research on the political economy of mass media also suggests that editorial filtering and the selection of certain topics can lead to adverse effects. If the media disseminate biased information, more information does not necessarily imply more transparency. In the Internet, editorial filtering is per se not a problem. Everyone can consume and produce information without any restriction and at reasonable costs. At the same time, the almost unlimited possibility to supply information bears the risk of an information overflow. As a result, people may concentrate on a limited number of topics and areas they want to hear and read about which may foster segregation and ideological polarization. An alternative reaction to an overflow of information would be that people demand aggregated sources of information. In this case, existing media outlets could simply use their infrastructure to provide their news and information through an additional channel, the Internet.

Our paper tests the effect of the Internet on different aspects of voting behavior. First, we look at voter participation and find statistically significant and negative effects of Internet access on voter turnout. Subsample estimations show no Internet effect on voter turnout in local elections but only on supra-regional elections. One possible explanation for this finding could be that the Internet crowds out other media that contain more or better information. TV is broadcasted nationally and does not help explain this finding. By contrast, newspapers are less homogeneous. On the one hand, there are national newspapers that distribute supra-regional information for a large audience. These newspapers are indeed affected by the Internet as new channel to disseminate information on a broad scale. On the other hand, there are local newspapers with an endemic focus. Clearly, there are less scale economies in the dissemination of region-specific information by the Internet and accordingly, we find that the Internet exerts higher competitive pressure on national newspapers than on local newspapers. This crowding-out of national newspapers may affect the dissemination of supra-regional information which translates into a lower voter turnout in supra-regional elections. Beyond the effect on voter turnout, we find some indication of a negative effect of Internet availability on extremist right wing parties’ vote shares. Other parties' vote shares are not systematically affected by the availability of broadband Internet. 
Taken together, we believe that our instrumental variable strategy enables us to report first causal evidence for an Internet effect on different aspects of voting behavior. However, we should also stress that our paper only analyses the introduction of the Internet. Further research is needed to assess whether the estimated effects persist when considering additional mobilization effects from web 2.0 applications like blogs or Facebook. Web 2.0 applications might especially be of interest for people who are interested in topics off the main policy issues. Before the Web 2.0 era, voting for small parties without a chance to win a significant vote share was one way to make a political statement. In the Web 2.0 era, blogging may be a more effective way to express political opinions on specific topics. However, these recent developments are not yet covered in our election data and thus remain the subject of future research. 


\section{References}

Anell, P., S. Jay, and T. Plückebaum (2007). Nachfrage nach Internetdiensten - Dienstearten, Verkehrseigenschaften und Quality of Service, wik Discussion Paper 302.

Bauernschuster, S., O. Falck, and L. Woessmann (2011). Surfing Alone? The Internet and Social Capital: Evidence from an Unforeseeable Technological Mistake. IZA Discussion Paper 5747.

Bruns, C. and O. Himmler (2011). Newspaper Circulation and Local Government Efficiency. Scand. Journal of Economics 113(2): 470-492.

Czernich, N., Falck, O., T. Kretschmer, and L. Woessmann (2011). Broadband Infrastructure and Economic Growth, Economic Journal, 121(May): 505-532.

Besley, T. and A. Prat (2006). Handcuffs for the Grabbing Hand? The Role of the Media in Political Accountability. American Economic Review 96(3): 720-736.

Besley, T. and R. Burgess (2002). The Political Economy of Government Responsiveness: Theory and Evidence from India, Quarterly Journal of Economics 117 (4): 1414-1451.

Bundesnetzagentur, (2000). Jahresbericht 1999, Bonn.

Bundesnetzagentur, (2001). Jahresbericht 2000, Bonn.

Campante, F. R. and D. Hojman (2010). Media and Polarization. Working Paper, Harvard Kennedy School.

Charles, K. K. and M. Stephens Jr. (2011). Employment, Wages and Voter Turnout, NBER Working Paper 17270.

DellaVigna, S. and E. Kaplan (2007). The Fox News Effect: Media Bias and Voting, Quarterly Journal of Economics 122 (3): 1187-1234.

Durante, R., and B. Knight (2011). Partisan Control, Media Bias, and Viewer Responses: Evidence from Berlusconi's Italy, Journal of European Economic Association, forthcoming.

Enikolopov, R., M. Petrova, and E. V. Zhuravskaya (2011). Media and Political Persuasion: Evidence from Russia, American Economic Review 101(7): 3253-3285.

Gentzkow, M. (2006). Television and Voter Turnout, Quarterly Journal of Economics 121 (3): 931-972.

Gentzkow, M. and J. Shapiro (2010a). What Drives Media Slant? Evidence from U.S. Daily Newspapers, Econometrica 78(1): 35-71.

Gentzkow M. and J. M. Shapiro (2010b). Ideological Segregation Online and Offline, Quarterly Journal of Economics 126(4): 1799-1839. 
Gentzkow, M., J. Shapiro, and M. Sinkinson (2011). The Effect of Newspaper Entry and Exit on Electoral Politics, American Economic Review, 101: 2980-3018.

Initiative D21 (2010). (N)ONLINER Atlas 2010. Berlin.

Kolko, J. (2012). Broadband and Local Growth. Journal of Urban Economics 71(1): 100-113.

Liebowitz, S. J., and A. Zentner (2011). Clash of the Titans: Does Internet Use Reduce Television Viewing? Review of Economics Statistics, forthcoming.

McMillan, J. and P. Zoido (2004). How to Subvert Democracy: Montesinos in Peru, Journal of Economic Perspectives 18(4): 69-92.

Oberholzer-Gee, F. and J. Waldfogel (2009). Media Markets and Localism: Does Local News en Espanol Boost Hispanic Voter Turnout? American Economic Review 99(5): 2120-28.

Olken, B.A. (2009). Do Television and Radio Destroy Social Capital? Evidence From Indonesian Villages. American Economic Journal: Applied Economics 1(4): 1-33.

Prat, A. and D. Strömberg (2006). Commercial Television and Voter Information. CEPR Discussion Paper No. 4989.

Prat, A. and D. Strömberg (2011). The Political Economy of Mass Media. Stockholm University Working Paper.

Puglisi, R. and J. M. Snyder, Jr. (2011). News Coverage of Political Scandals, Journal of Politics 73(3): 931-950.

Putnam, R. D. (1993). Making Democracy Work. Civic Traditions in Modern Italy. Princeton, NJ: Princeton University Press.

Putnam, R.D. (2000). Bowling Alone : The Collapse and Revival of American Community. New York: Simon \& Schuster.

Snyder, J. M. and D. Strömberg (2010). Press Coverage and Political Accountability. Journal of Political Economy 118(2): 355-408.

Strömberg, D. (2004a). Radios Impact on Public Spending. Quarterly Journal of Economics 119(1):189-221.

Strömberg, D. (2004b). Mass Media Competition, Political Competition, and Public Policy. Review of Economic Studies 71(1): 265-284.

Sunstein, C. R. (2001). Republic.com. Princeton, NJ: Princeton University Press.

Voigtlaender, N. and J. Voth (2012). Persecution Perpetuated: Medieval of Anti-Semitic Violence in Nazi Germany, Quarterly Journal of Economics, forthcoming. 
Figure 1: Development of Broadband Subscriptions in Germany by Technology

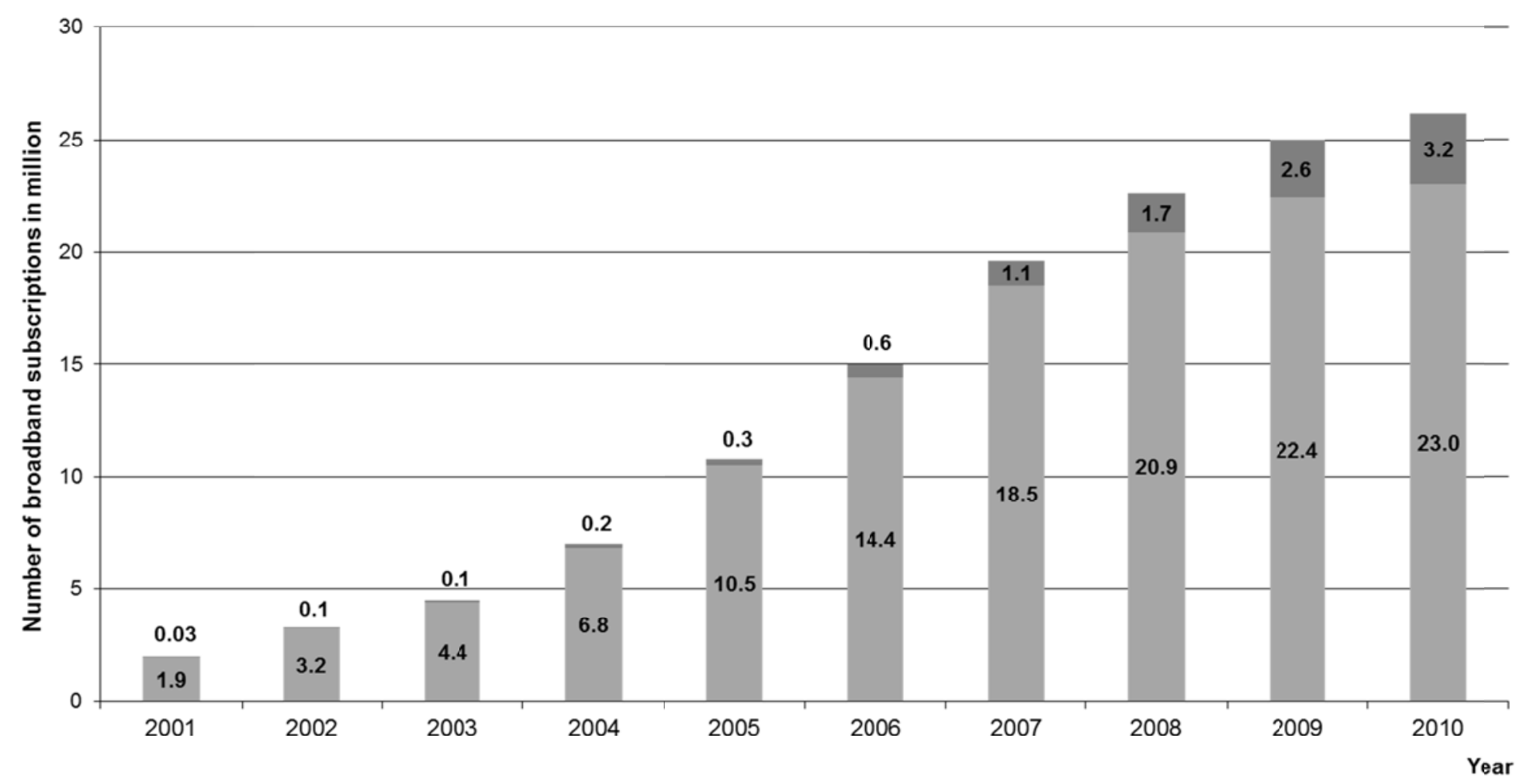

$=\mathrm{DSL}$ subscriptions $\quad$ other technologies

Notes: Bundesnetzagentur 2010. The figure shows the development of broadband subscriptions in Germany. The lower, lighter bars show the number of DSL subscriptions that are realized via DSL. The upper, darker bars represent the number of broadband subscriptions that are realized via other technologies, mainly via the cable TV network. 
Figure 2: DSL Availability across German Municipalities, 2005-2008
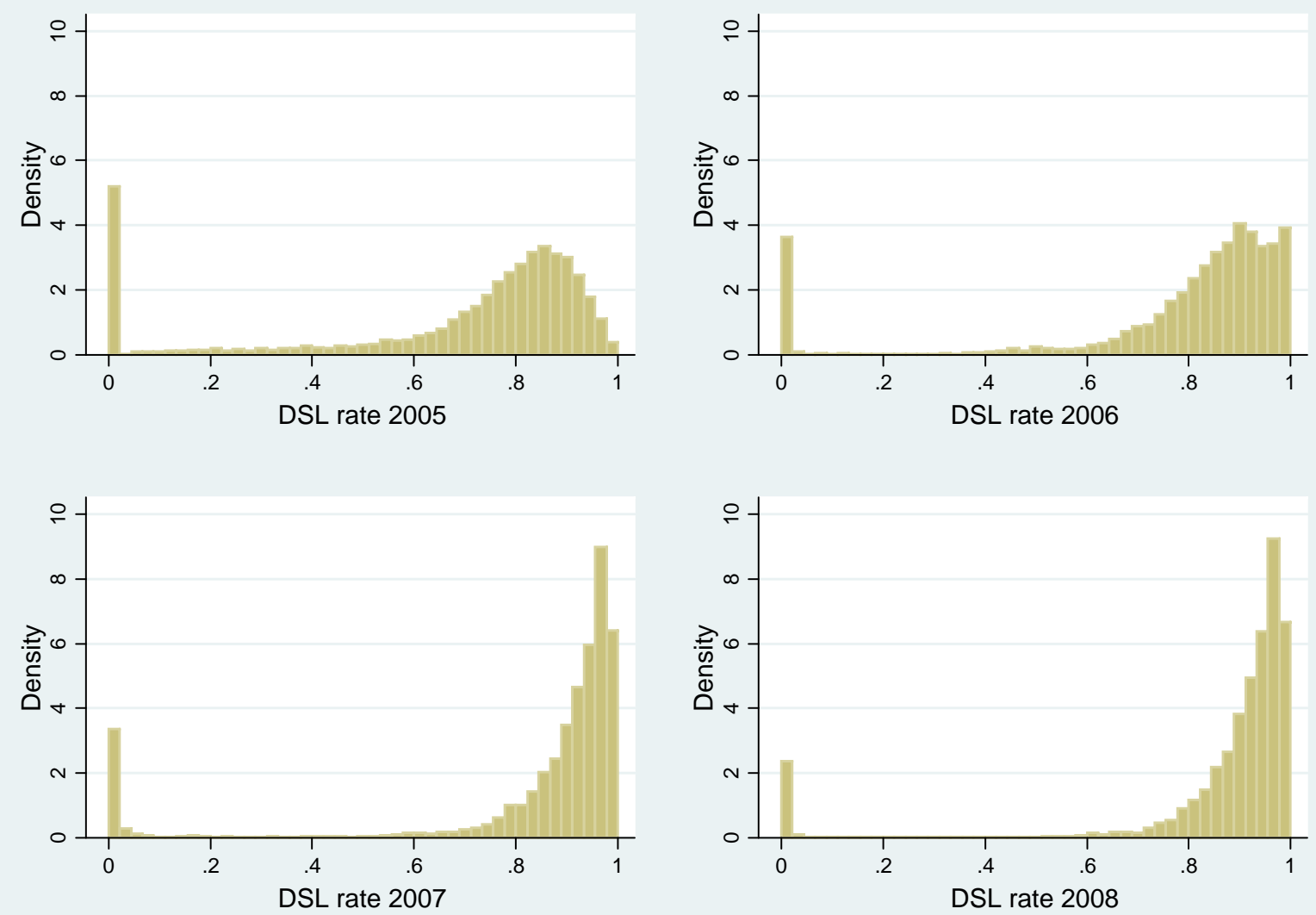

Notes: The Figure shows Histograms of the DSL rate across12,202 municipalities in the years 2005-2008. 
Table 1: Internet Usage

\begin{tabular}{lcccccc}
\hline & Yes & $\%$ & No & $\%$ & No answer & Total \\
\hline \hline News & 13,594 & $71.7 \%$ & 5,312 & $28.0 \%$ & 48 & 18,954 \\
Information search & 17,939 & $94.6 \%$ & 984 & $5.2 \%$ & 31 & 18,954 \\
Entertainment & 9,258 & $48.8 \%$ & 9,581 & $50.5 \%$ & 115 & 18,954 \\
Services & 10,400 & $54.9 \%$ & 8,481 & $44.7 \%$ & 73 & 18,954 \\
Shopping & 10,475 & $55.3 \%$ & 8,418 & $44.4 \%$ & 61 & 18,954 \\
Banking & 8,326 & $43.9 \%$ & 10,550 & $55.7 \%$ & 78 & 18,954 \\
Discussion forums & 6,153 & $32.5 \%$ & 12,727 & $67.1 \%$ & 74 & 18,954 \\
E-Mail & 16,937 & $89.4 \%$ & 1,984 & $10.5 \%$ & 33 & 18,954 \\
\hline
\end{tabular}

Notes: Survey by Arbeitsgemeinschaft Media Anaylse in 2007 among 18,954 Internet users. Interviewees were asked for which purpose they use the Internet. Multiple answers were allowed. 
Table 2: The Timing of Elections

\begin{tabular}{|c|c|c|c|c|}
\hline & $\begin{array}{c}\text { pre-pre-period } \\
(1990-1994)\end{array}$ & $\begin{array}{c}\text { pre-period } \\
(1995-1999) \\
\end{array}$ & $\begin{array}{c}\text { post-period } \\
(2004-2008) \\
\end{array}$ & election type \\
\hline \multirow{3}{*}{ Schleswig-Holstein } & 1994 & 1998 & 2005 & federal \\
\hline & - & 1996 & 2005 & state \\
\hline & - & 1998 & 2008 & local \\
\hline \multirow{3}{*}{ Lower Saxony } & 1994 & 1998 & 2005 & federal \\
\hline & 1990 & 1998 & 2008 & state \\
\hline & 1991 & 1996 & 2006 & local \\
\hline \multirow{3}{*}{ North Rhine-Westphalia } & 1994 & 1998 & 2005 & federal \\
\hline & 1990 & 1995 & 2005 & state \\
\hline & 1994 & 1999 & 2004 & local \\
\hline \multirow{3}{*}{ Hesse } & 1994 & 1998 & 2005 & federal \\
\hline & 1991 & 1995 & 2008 & state \\
\hline & 1993 & 1997 & 2006 & local \\
\hline \multirow{3}{*}{ Rhineland-Palatinate } & 1994 & 1998 & 2005 & federal \\
\hline & 1991 & 1996 & 2006 & state \\
\hline & 1994 & 1999 & 2004 & local \\
\hline \multirow{3}{*}{ Baden-Wuerttemberg } & 1994 & 1998 & 2005 & federal \\
\hline & 1992 & 1996 & 2006 & state \\
\hline & 1994 & 1999 & 2004 & local \\
\hline \multirow{3}{*}{ Bavaria } & 1994 & 1998 & 2005 & federal \\
\hline & 1994 & 1998 & 2008 & state \\
\hline & 1990 & 1996 & 2008 & local \\
\hline \multirow{3}{*}{ Saarland } & 1994 & 1998 & 2005 & federal \\
\hline & 1990 & 1999 & 2004 & state \\
\hline & 1994 & 1999 & 2004 & local \\
\hline \multirow{3}{*}{ Brandenburg } & 1994 & 1998 & 2005 & federal \\
\hline & 1990 & 1999 & 2004 & state \\
\hline & 1993 & 1998 & 2008 & local \\
\hline \multirow{3}{*}{$\begin{array}{l}\text { Mecklenburg- } \\
\text { Western Pomerania }\end{array}$} & 1994 & 1998 & 2005 & federal \\
\hline & 1990 & 1998 & 2006 & state \\
\hline & 1994 & 1999 & 2004 & local \\
\hline \multirow{3}{*}{ Saxony } & 1994 & 1998 & 2005 & federal \\
\hline & 1990 & 1999 & 2004 & state \\
\hline & 1994 & 1999 & 2004 & local \\
\hline \multirow{3}{*}{ Saxony-Anhalt } & 1994 & 1998 & 2005 & federal \\
\hline & 1990 & 1998 & 2006 & state \\
\hline & 1994 & 1999 & 2004 & local \\
\hline \multirow{3}{*}{ Thuringia } & 1994 & 1998 & 2005 & federal \\
\hline & 1990 & 1999 & 2004 & state \\
\hline & 1994 & 1999 & 2004 & local \\
\hline
\end{tabular}

Notes: The Table plots the elections years employed in the paper by state, period (relative to DSL rollout), and election type (level of governance). 
Table 3: Summary Statistics on Election Outcomes, 2004 - 2008

\begin{tabular}{|c|c|c|c|c|c|}
\hline & Observations & Mean & Std. Dev. & Min & Max \\
\hline \multicolumn{6}{|l|}{ National Elections } \\
\hline Turnout & 12205 & 0.728 & 0.070 & 0.396 & 0.957 \\
\hline Vote share established parties & 12205 & 0.851 & 0.109 & 0.478 & 1 \\
\hline Vote share ext. left-wing parties & 12205 & 0.105 & 0.099 & 0.000 & 0.449 \\
\hline \multicolumn{6}{|l|}{ State Elections } \\
\hline Turnout & 12205 & 0.591 & 0.098 & 0.280 & 1 \\
\hline Vote share established parties & 12205 & 0.817 & 0.123 & 0.345 & 1 \\
\hline Vote share ext. right-wing parties & 12205 & 0.034 & 0.034 & 0.000 & 0.382 \\
\hline Vote share ext. left-wing parties & 12205 & 0.085 & 0.093 & 0.000 & 0.482 \\
\hline \multicolumn{6}{|l|}{ Municipality Elections } \\
\hline Turnout & 10783 & 0.609 & 0.105 & 0.271 & 1 \\
\hline Vote share established parties & 10783 & 0.548 & 0.336 & 0.000 & 1 \\
\hline Vote share ext. right-wing parties & 10783 & 0.001 & 0.008 & 0.000 & 0.252 \\
\hline Vote share ext. left-wing parties & 10783 & 0.030 & 0.070 & 0.000 & 0.988 \\
\hline
\end{tabular}

Notes: The Table presents descriptive statistics for our four outcome variables Turnout, by election type in the Internet era, i.e. the post-rollout period from 2004 to 2008. 
Table 4: The Association Between High-Speed Internet Availability and Voting Outcomes

\begin{tabular}{|c|c|c|c|c|c|c|c|c|}
\hline & \multicolumn{2}{|c|}{ Turnout } & \multicolumn{2}{|c|}{$\begin{array}{c}\text { Vote share } \\
\text { Established Parties }\end{array}$} & \multicolumn{2}{|c|}{$\begin{array}{l}\text { Vote share } \\
\text { Extreme right-wing parties }\end{array}$} & \multicolumn{2}{|c|}{$\begin{array}{l}\text { Vote share } \\
\text { Extreme left-wing parties }\end{array}$} \\
\hline & (1) & (2) & (3) & (4) & (5) & (6) & (7) & (8) \\
\hline DSL availability & $\begin{array}{c}-0.022 * * * \\
(0.002)\end{array}$ & $\begin{array}{c}-0.015^{* * *} \\
(0.002)\end{array}$ & $\begin{array}{c}0.028 * * * \\
(0.004)\end{array}$ & $\begin{array}{c}0.011 * * * \\
(0.002)\end{array}$ & $\begin{array}{c}0.000 \\
(0.001)\end{array}$ & $\begin{array}{c}0.002^{* * *} \\
(0.001)\end{array}$ & $\begin{array}{r}0.004^{* *} \\
(0.002)\end{array}$ & $\begin{array}{c}-0.007 * * * \\
(0.001)\end{array}$ \\
\hline $\begin{array}{l}\text { Pre-broadband Internet election } \\
\text { outcome }\end{array}$ & - & $\begin{array}{c}0.741^{* * *} \\
(0.006)\end{array}$ & - & $\begin{array}{c}0.843^{* * *} \\
(0.005)\end{array}$ & - & $\begin{array}{l}0.456^{* * * *} \\
(0.008)\end{array}$ & - & $\begin{array}{c}0.896^{* * *} \\
(0.014)\end{array}$ \\
\hline Number of observations & 34,759 & 34,759 & 34,759 & 34,759 & 34,759 & 34,759 & 34,759 & 34,759 \\
\hline $\mathrm{R}^{2}$ & 0.596 & 0.775 & 0.591 & 0.880 & 0.537 & 0.633 & 0.714 & 0.883 \\
\hline
\end{tabular}

Notes: The Table shows municipality-level pooled regressions for elections after 2004 at three main levels of governance in Germany, i.e. elections for the Federal Parliament (Bundestagswahlen), elections for the State Parliaments (Landtagswahlen), and elections for the municipal- or city councils (Gemeinderatswahlen or Stadtratswahlen). All regressions include municipality characteristics (surface, population, female population share, age structure of the population, and unemployment rate), election type dummies, county dummies, and year dummies. Standard errors are clustered on the municipality-level.

*** $1 \%$ significance level; ** 5\% significance level; * $10 \%$ significance level. 


\section{Figure 3: The Structure of a DSL Network}

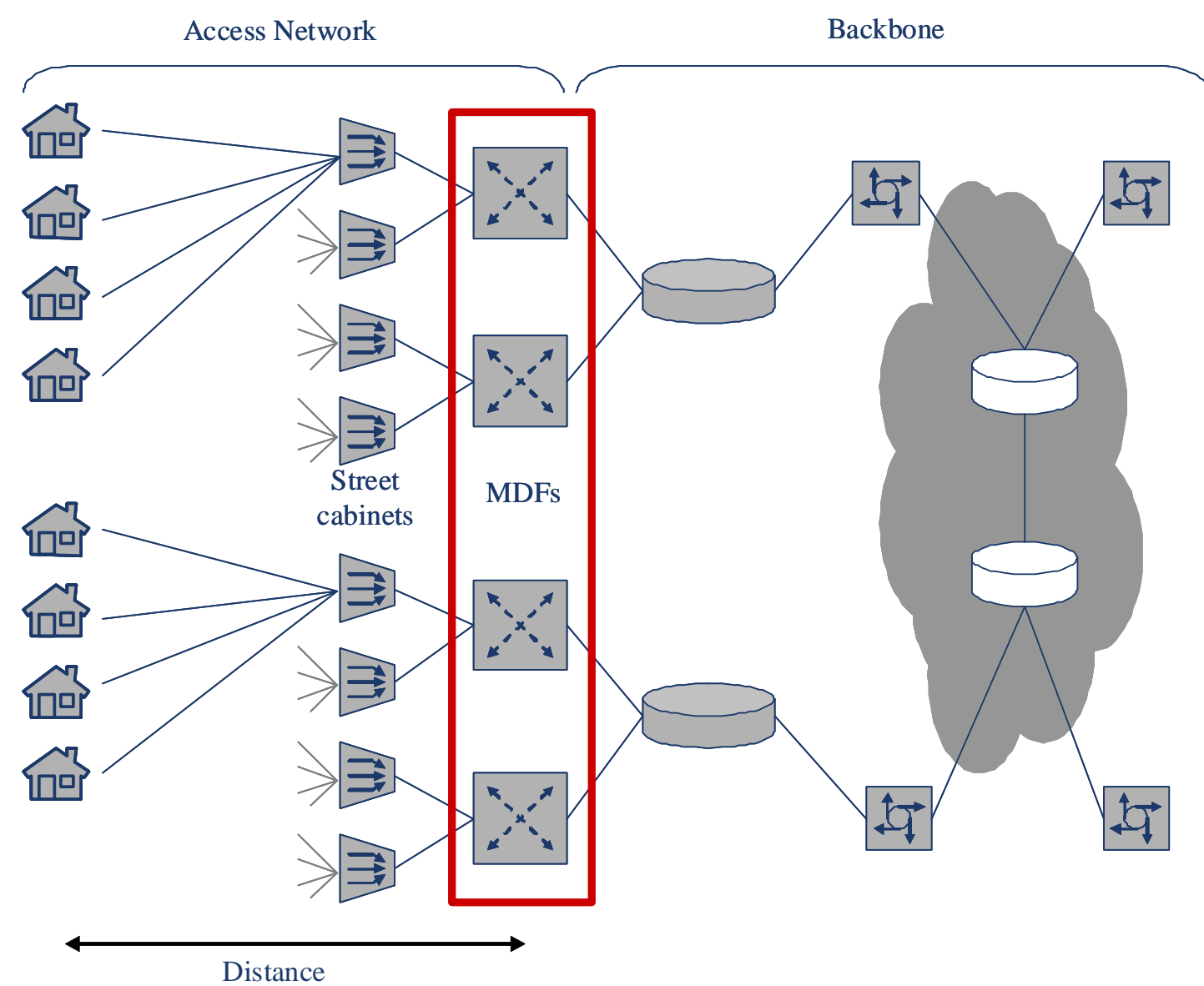

Notes: The access network is based on the traditional copper wires of the public switched telephone network (PSTN). The early generations of DSL technology connect the copper wires of the access network to the backbone network at the main distribution frame by means of a DSLAM (Digital Subscriber Line Access Multiplexer). This structure allows bandwidth of up to $16 \mathrm{Mbit} / \mathrm{s}$. For the newer VDSL technology which allows bandwidths of up to $50 \mathrm{Mbit} / \mathrm{s}$ and for areas where the distance between households and MDFs are too long to make DSL feasible the copper wire between the MDF and a node which is nearer to the household, e.g., a street cabinet is bypassed by fiber wire and an (Outdoor-) DSLAM is installed at this node (street cabinet). Source: Anell et al. (2007). 
Figure 4: The Spatial Distribution of Main Distribution Frames (MDF) in Germany

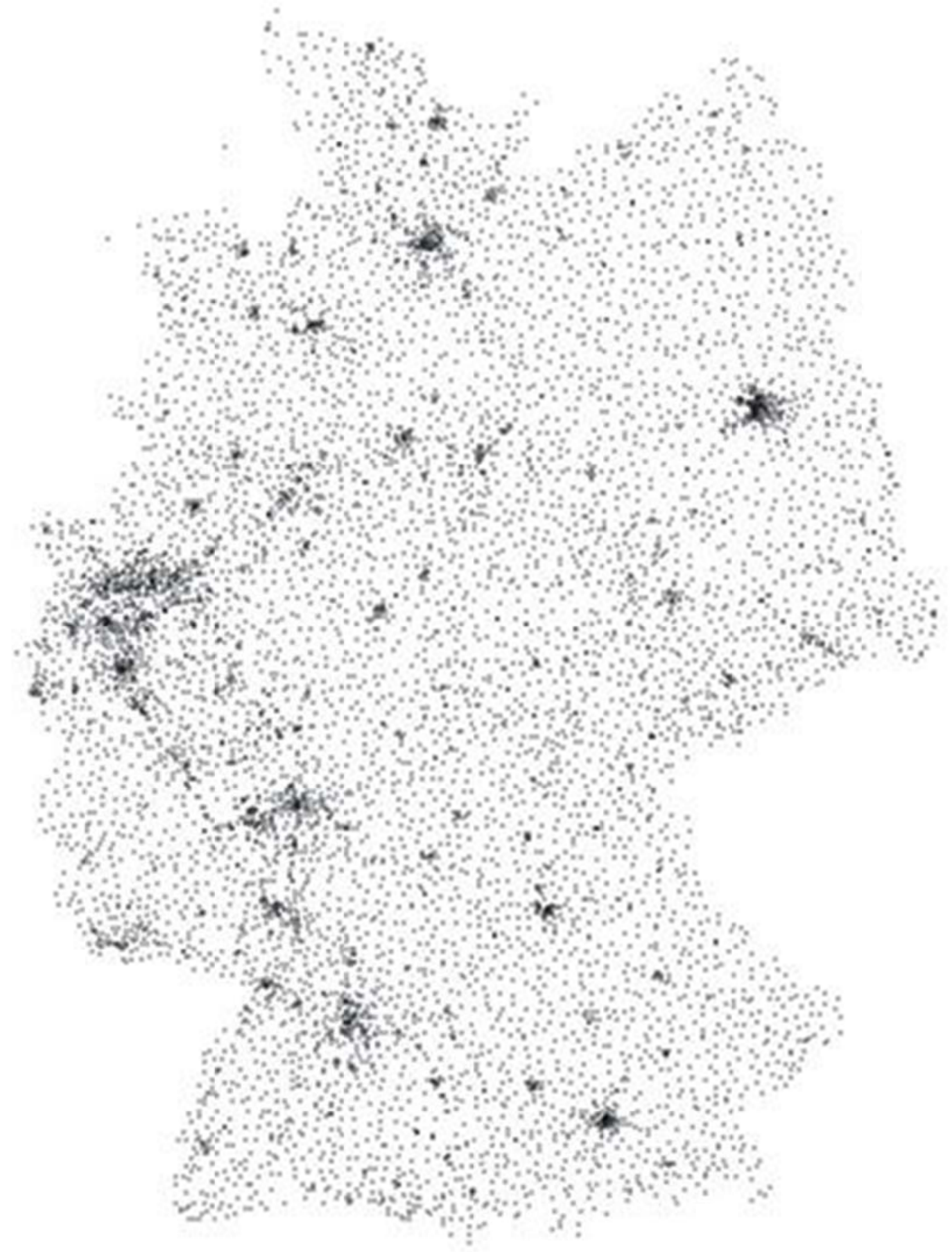

Notes: The map shows the spatial distribution of the more than 8,000 main distribution frames (MDF) in Germany. 
Figure 5: The Relationship between DSL Availability in a Municipality and Distance to MDF

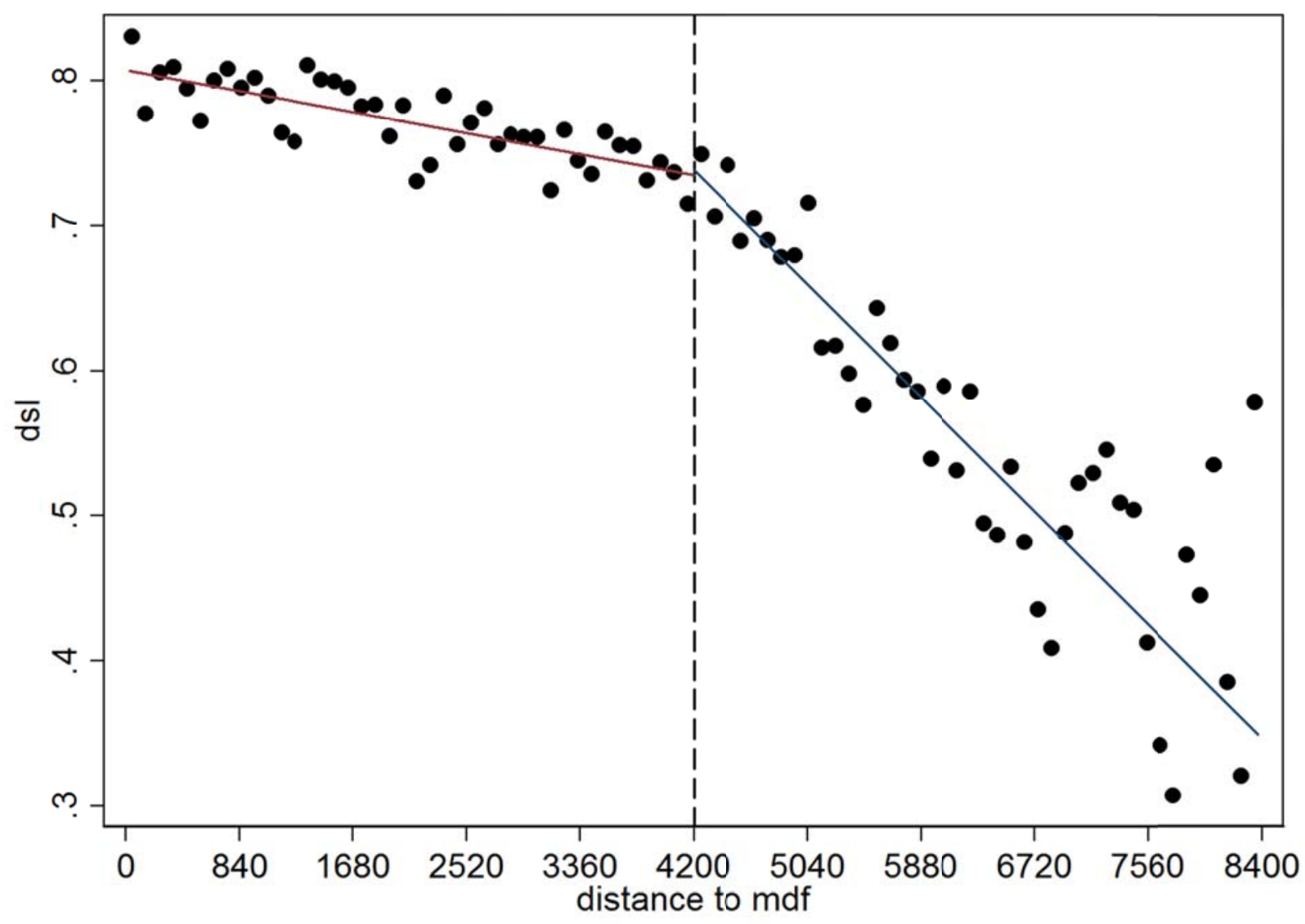

Notes: The Figure plots the share of households with DSL access in a municipality (municipalities are averaged across bins of 100 meter) against the distance from the geographic centroid of the municipality to the actual main distribution frame (MDF). The red line to the left of the technological threshold and the blue line to the right of the threshold are both fitted lines on the basis of individual observations. 
Figure 6: The Geographic Layout of Telephone Access Areas in Germany

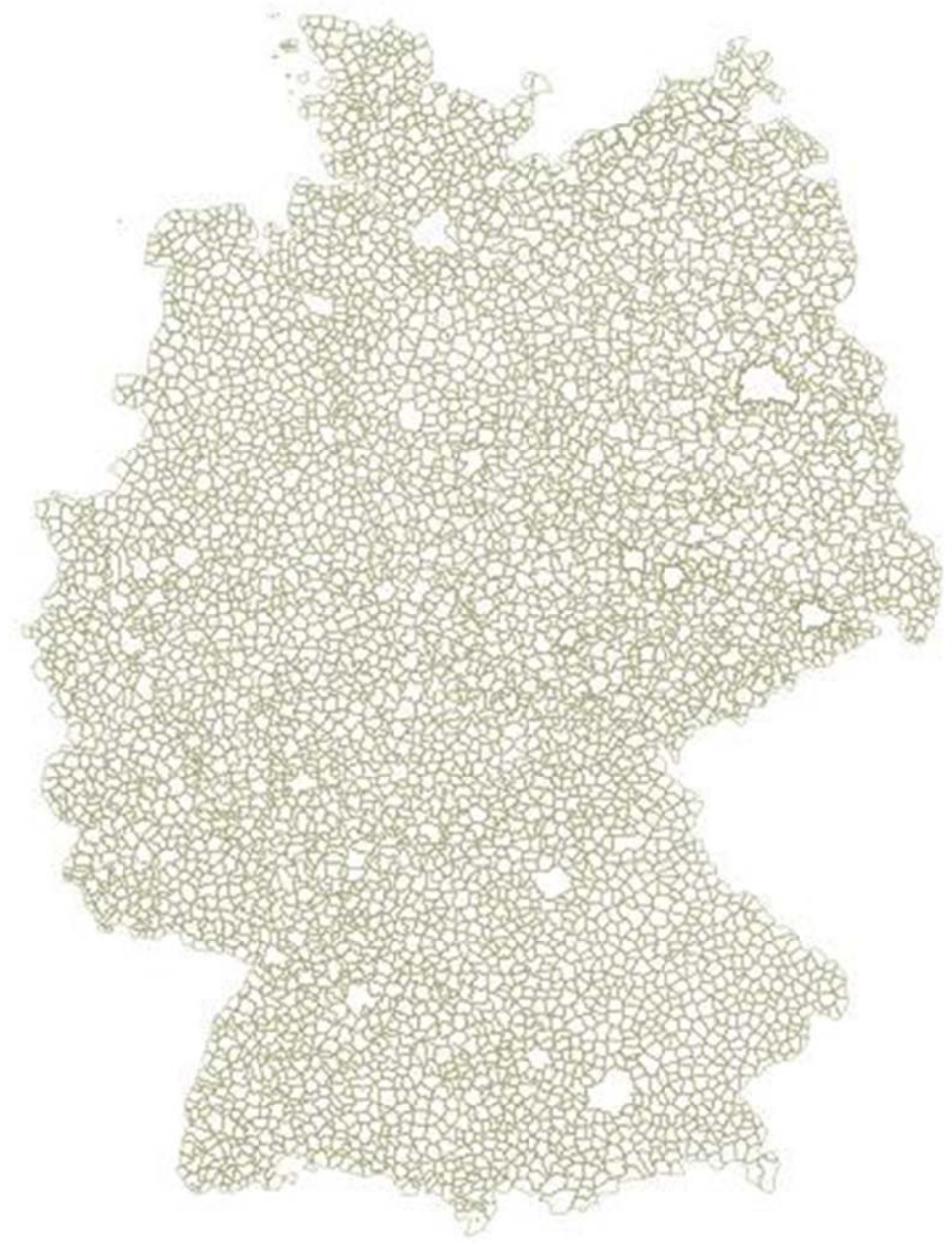

Notes: The map shows the geographic layout of the more than 5,000 telephone access areas in Germany. 
Figure 7: OPAL Access Nodes in East Germany

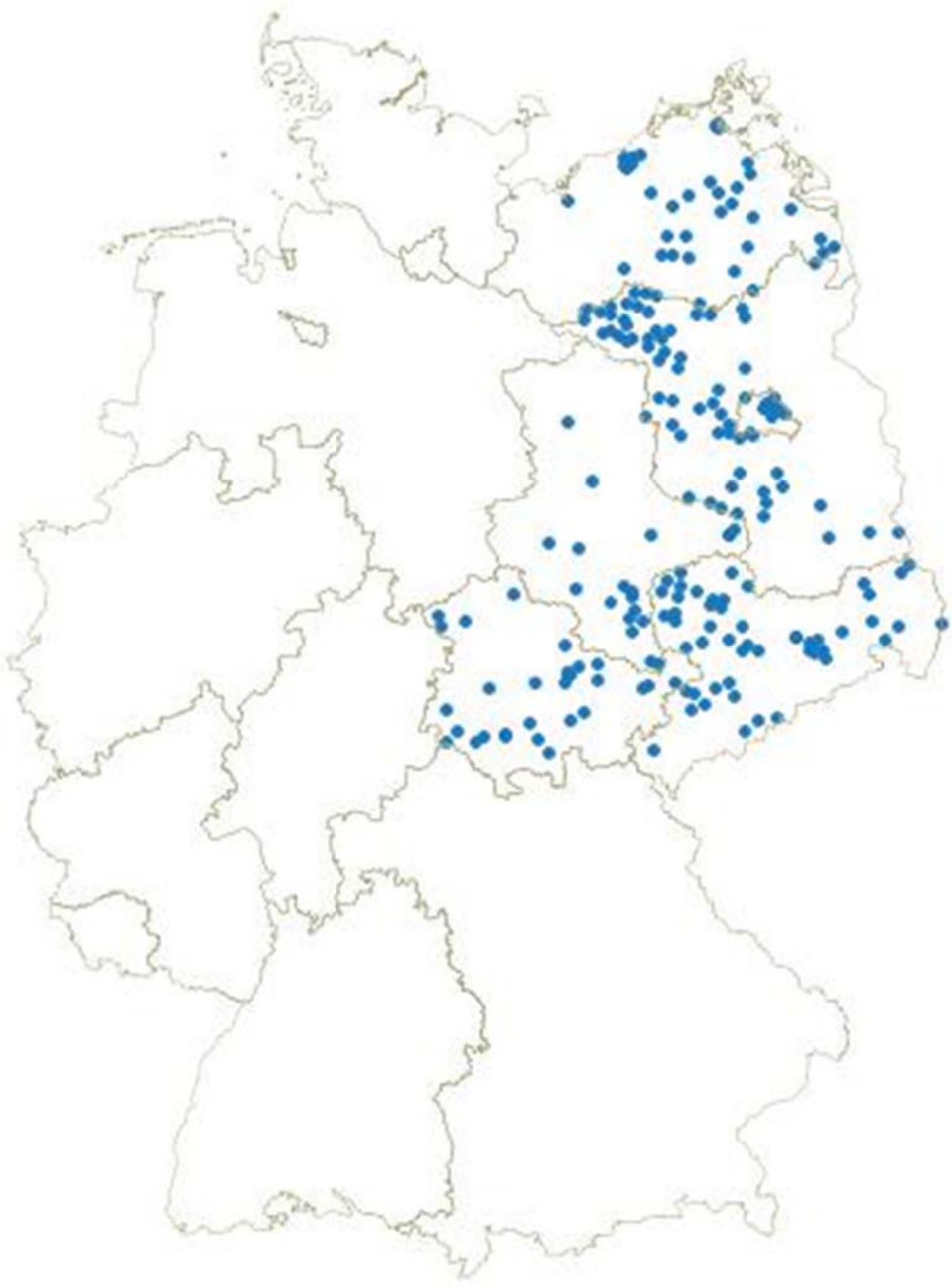

Notes: The map shows the Opal access nodes in East German that provided about 11 percent of the East German population with OPAL technology. 
Table 5: DSL Availability in Municipalities and Characteristics of the Pre-Existing Voice-Telephony Network

\begin{tabular}{lc}
\hline & DSL share \\
\hline \hline Centered Distance (in km) & -0.001 \\
& $(0.002)$ \\
Threshold (4.2 km) & $-0.031^{* * *}$ \\
Distance * threshold & $(0.008)$ \\
& $-0.059^{* * *}$ \\
“Wrong” MDF dummy & $(0.006)$ \\
& $0.023^{* * *}$ \\
Actual MDF $>4.2 \mathrm{~km} \&$ Closer MDF $<4.2 \mathrm{~km}$ & $(0.008)$ \\
& $0.084^{* * *}$ \\
OPAL dummy & $(0.011)$ \\
$\mathrm{R}^{2}$ & $-0.080^{* * *}$ \\
\hline
\end{tabular}

Notes: Municipality-level regression of technical characteristics of the pre-existing voice telephony network on the share of households for which DSL is technically feasible in a municipality conditional municipality characteristics. DSL availably is measured in the relevant years of elections. Distance is centered around the threshold at $4.2 \mathrm{~km}$. Distance related variables are calculated from the geographic centroids of the municipalities. $4.2 \mathrm{~km}$ are about 2.6 miles. *** $1 \%$ significance level; ** 5\% significance level; * $10 \%$ significance level. 
Table 6: Instrumental Variable Results

\begin{tabular}{|c|c|c|c|c|}
\hline & $\begin{array}{c}\text { VA } \\
\text { No own MDF }\end{array}$ & $\begin{array}{c}\text { IV } \\
\text { No own MDF } \\
\text { geographic centroid }\end{array}$ & $\begin{array}{c}\text { IV } \\
\text { No own MDF } \\
\text { population center }\end{array}$ & $\begin{array}{c}\text { Placebo } \\
\text { No own MDF } \\
\text { geographic centroid }\end{array}$ \\
\hline Voter turnout & $\begin{array}{c}(1) \\
-0.011^{* * *} \\
(0.002)\end{array}$ & $\begin{array}{c}(2) \\
-0.019 * * * \\
(0.007)\end{array}$ & $\begin{array}{c}(3) \\
-0.025^{* * *} \\
(0.006)\end{array}$ & $\begin{array}{c}(4) \\
0.006 \\
(0.006)\end{array}$ \\
\hline $\begin{array}{l}\text { Vote share } \\
\text { established parties }\end{array}$ & $\begin{array}{c}0.010^{* * *} \\
(0.003)\end{array}$ & $\begin{array}{c}0.013 \\
(0.010)\end{array}$ & $\begin{array}{c}0.007 \\
(0.010)\end{array}$ & $\begin{array}{c}0.014 \\
(0.011)\end{array}$ \\
\hline $\begin{array}{l}\text { Vote share } \\
\text { extreme right-wing parties }\end{array}$ & $\begin{array}{l}0.001 * * \\
(0.001)\end{array}$ & $\begin{array}{l}-0.004^{*} \\
(0.002)\end{array}$ & $\begin{array}{l}-0.003 \\
(0.002)\end{array}$ & $\begin{array}{c}0.000 \\
(0.002)\end{array}$ \\
\hline $\begin{array}{l}\text { Vote share } \\
\text { Extreme left-wing parties }\end{array}$ & $\begin{array}{c}-0.007 * * * \\
(0.001)\end{array}$ & $\begin{array}{c}0.001 \\
(0.004)\end{array}$ & $\begin{array}{l}-0.002 \\
(0.004)\end{array}$ & $\begin{array}{c}0.001 \\
(0.004)\end{array}$ \\
\hline Number of observation & 19,930 & 19,168 & 19,168 & 17,542 \\
\hline
\end{tabular}

Notes: Municipality-level pooled value-added regressions for elections at three main levels of governance in Germany, i.e. elections for the Federal Parliament (Bundestagswahlen), elections for the State Parliaments (Landtagswahlen), and elections for the municipal- or city councils (Gemeinderatswahlen or Stadtratswahlen). The first three columns refer to election outcomes after 2004. The fourth column refers to election outcomes before 2000. Each cell shows the DSL availability coefficient from a separate regression. All regressions include contemporaneous municipality characteristics (surface, population, female population share, age structure of the population, and unemployment rate), election type dummies, county dummies, and year dummies. Clustered standard errors on the municipality-level. *** 1\% significance level; ** 5\% significance level; * $10 \%$ significance level. 
Table 7: IV Regressions by Election Type

Vote share $\quad$ Vote share $\quad$ Vote share

$\begin{array}{ll}\text { Turnout } & \text { established parties extreme right-wing parties left-wing parties }\end{array}$

$$
\text { (1) }
$$

Federal elections (Municipalities without own MDF)

DSL availability

$-0.024 * * *$

0.002

(0.006)

6,800

6,800

0.913

$-0.006 * *$

0.003

Number of observations

$\mathrm{R}^{2}$

0.669

53.81

(0.003)

(0.005)

6,800

6,800

53.76

0.633

0.923

$\mathrm{F}$ test of ex. Instruments

$-0.019 * * *$

53.76

State elections (Municipalities without own MDF)

DSL availability

Number of observations

$\mathrm{R}^{2}$

(0.007)

6,796

$-0.001$

$-0.004$

0.001

0.765

(0.007)

6,796

(0.003)

(0.005)

80.95

0.883

6,796

6,796

F test of ex. Instruments

80.81

0.748

0.913

80.97

80.95

\begin{tabular}{|c|c|c|c|c|}
\hline \multirow{2}{*}{\multicolumn{5}{|c|}{ Municinality elections (Municinalitios without own MDF) }} \\
\hline & MDF) & & & \\
\hline \multirow{2}{*}{ DSL availability } & -0.010 & 0.059 & 0.000 & -0.015 \\
\hline & $(0.017)$ & $(0.042)$ & $(0.002)$ & $(0.012)$ \\
\hline Number of observations & 5,572 & 5,572 & 5,572 & 5,572 \\
\hline $\mathrm{R}^{2}$ & 0.663 & 0.821 & 0.286 & 0.650 \\
\hline F test of ex. Instruments & 25.58 & 26.05 & 26.27 & 26.33 \\
\hline
\end{tabular}

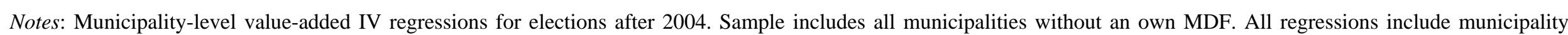

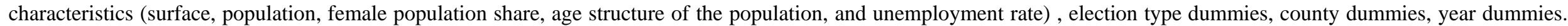
Distance related instruments are calculated from the geographic centroids of the municipalities. Clustered standard errors on the municipality-level.

*** $1 \%$ significance level; ** $5 \%$ significance level; * $10 \%$ significance level. 
Figure 8: National and Local Newspaper Circulation

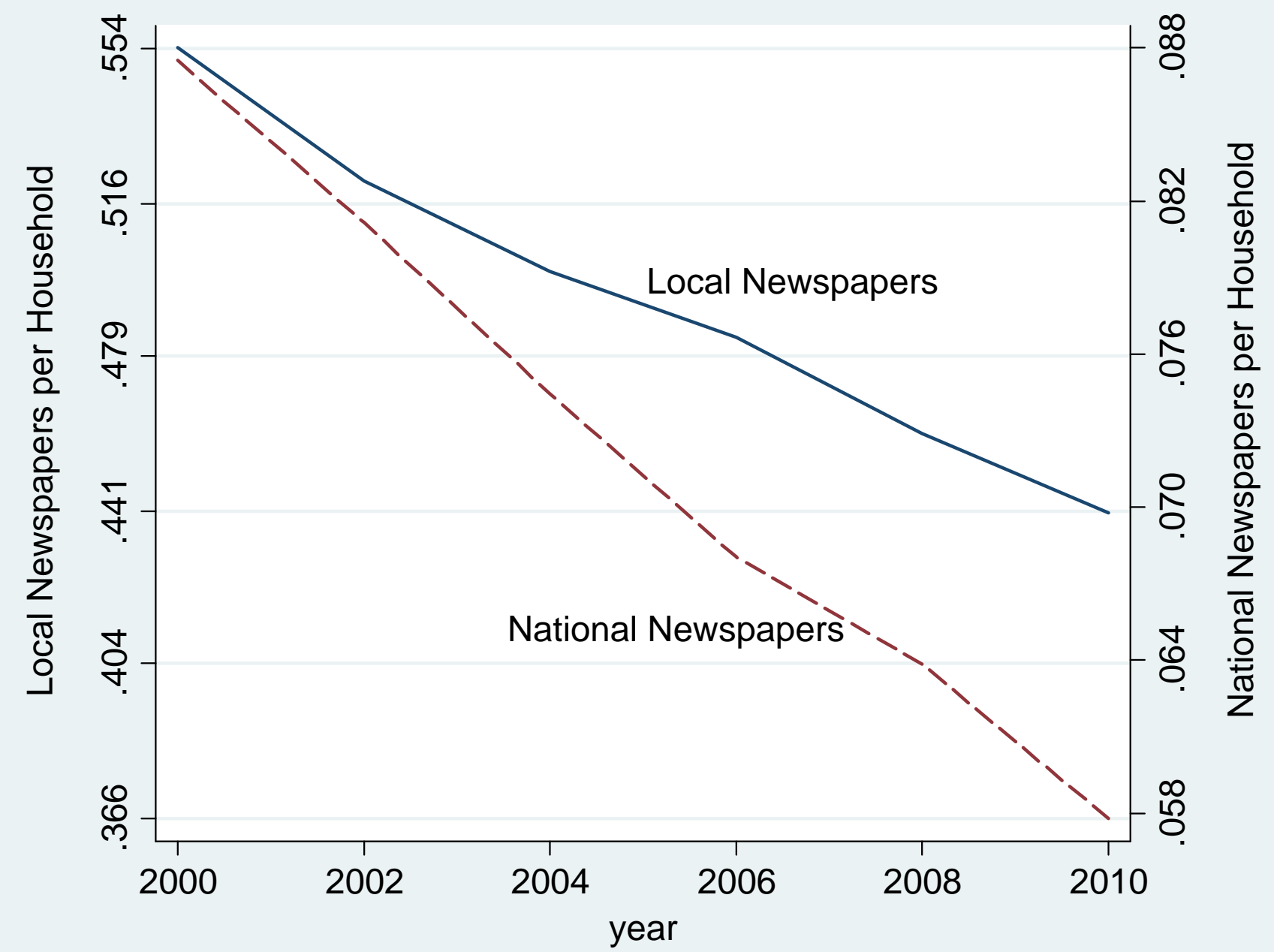

Notes: The Figure shows the development of the average number of daily local (solid line) and daily national (dashed line) newspapers per household across the subsample of municipalities without an own MDF. The scales are proportionate. 


\begin{tabular}{|c|c|c|c|c|c|c|}
\hline & \multicolumn{2}{|c|}{ SUR } & \multicolumn{2}{|c|}{ SUR } & \multicolumn{2}{|c|}{ SUR } \\
\hline & $\begin{array}{c}\text { Local } \\
\text { Newspapers }\end{array}$ & $\begin{array}{c}\text { National } \\
\text { Newspapers }\end{array}$ & $\begin{array}{c}\text { Local } \\
\text { Newspapers }\end{array}$ & $\begin{array}{c}\text { National } \\
\text { Newspapers }\end{array}$ & $\begin{array}{c}\text { Local } \\
\text { Newspapers }\end{array}$ & $\begin{array}{c}\text { National } \\
\text { Newspapers }\end{array}$ \\
\hline & (1) & $(2)$ & (3) & (4) & (5) & (6) \\
\hline \multicolumn{7}{|l|}{ Growth 2004-2006 } \\
\hline DSL availability & $\begin{array}{c}0.025^{* * * *} \\
(0.007)\end{array}$ & $\begin{array}{c}-0.065^{* * *} \\
(0.025)\end{array}$ & $\begin{array}{c}0.008 \\
(0.008)\end{array}$ & $\begin{array}{c}-0.067 * * \\
(0.028)\end{array}$ & $\begin{array}{c}0.012 \\
(0.008)\end{array}$ & $\begin{array}{l}-0.039 \\
(0.028)\end{array}$ \\
\hline Equality of DSL coefficients & \multicolumn{2}{|c|}{$11.79 * * *$} & \multicolumn{2}{|c|}{$6.70 * * *$} & \multicolumn{2}{|c|}{$3.21 *$} \\
\hline Controls & - & - & $\mathrm{Y}$ & $\mathrm{Y}$ & $\mathrm{Y}$ & $\mathrm{Y}$ \\
\hline $\log ($ local or national newspapers per HH in 2004) & - & - & - & - & $\mathrm{Y}$ & $\mathrm{Y}$ \\
\hline Number of observations & 5,413 & 5,413 & 5,375 & 5,375 & 5,375 & 5,375 \\
\hline $\mathrm{R}^{2}$ & 0.003 & 0.001 & 0.018 & 0.007 & 0.116 & 0.042 \\
\hline \multicolumn{7}{|l|}{ Growth 2004-2008 } \\
\hline DSL availability & $\begin{array}{c}0.029 * * * \\
(0.008)\end{array}$ & $\begin{array}{c}-0.069 * * \\
(0.031)\end{array}$ & $\begin{array}{c}0.006 \\
(0.008)\end{array}$ & $\begin{array}{c}-0.111^{* * *} \\
(0.034)\end{array}$ & $\begin{array}{l}0.0103 \\
(0.008)\end{array}$ & $\begin{array}{c}-0.065^{* *} \\
(0.033)\end{array}$ \\
\hline Equality of DSL coefficients & \multicolumn{2}{|c|}{$9.68 * * *$} & \multicolumn{2}{|c|}{$11.29 * * *$} & \multicolumn{2}{|c|}{$5.10 * *$} \\
\hline Controls & - & - & $\mathrm{Y}$ & $\mathrm{Y}$ & $\mathrm{Y}$ & $\mathrm{Y}$ \\
\hline log(local or national newspapers per HH in 2004) & - & - & - & - & $\mathrm{Y}$ & $\mathrm{Y}$ \\
\hline Number of observations & 5,369 & 5,369 & 5,331 & 5,331 & 5,331 & 5,331 \\
\hline $\mathrm{R}^{2}$ & 0.003 & 0.001 & 0.025 & 0.003 & 0.170 & 0.082 \\
\hline \multicolumn{7}{|l|}{ Growth 2004-2010 } \\
\hline DSL availability & $\begin{array}{c}0.054^{* * *} \\
0.009\end{array}$ & $\begin{array}{l}0.001 \\
0.034\end{array}$ & $\begin{array}{c}0.020 * * \\
(0.009)\end{array}$ & $\begin{array}{l}-0.060 \\
(0.038)\end{array}$ & $\begin{array}{c}0.029 * * * \\
(0.008)\end{array}$ & $\begin{array}{c}0.003 \\
(0.036)\end{array}$ \\
\hline Equality of DSL coefficients & \multicolumn{2}{|c|}{2.22} & \multicolumn{2}{|c|}{$4.32 * *$} & \multicolumn{2}{|c|}{0.52} \\
\hline Controls & - & - & $\mathrm{Y}$ & $\mathrm{Y}$ & $\mathrm{Y}$ & $\mathrm{Y}$ \\
\hline log(local or national newspapers per HH in 2004) & - & - & - & - & $\mathrm{Y}$ & $\mathrm{Y}$ \\
\hline Number of observations & 5,172 & 5,172 & 5,172 & 5,172 & 5,172 & 5,172 \\
\hline $\mathrm{R}^{2}$ & 0.008 & 0.000 & 0.060 & 0.004 & 0.238 & 0.107 \\
\hline
\end{tabular}

Notes: Municipality-level three equations seemingly unrelated regressions. Sample includes all municipalities without an own MDF. Only first two equations are shown in the

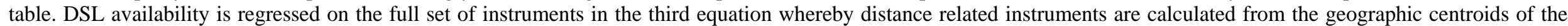
municipalities. Controls include surface, population, female population share, age structure of the population, and the unemployment rate.

*** $1 \%$ significance level; ** 5\% significance level; * $10 \%$ significance level. 
Table 9: DSL Availability and Unemployment

\begin{tabular}{lccc}
\hline & $\begin{array}{c}\text { VA } \\
\text { all }\end{array}$ & $\begin{array}{c}\text { VA } \\
\text { no MDF }\end{array}$ & $\begin{array}{c}\text { IV } \\
\text { no MDF } \\
\text { centroid }\end{array}$ \\
\hline \hline & $(1)$ & $(2)$ & $(3)$ \\
DSL share & $-0.008^{* * *}$ & $-0.007^{* * *}$ & 0.003 \\
Pre-broadband Internet & $(0.001)$ & $(0.001)$ & $(0.003)$ \\
unemployment & $0.764^{* * *}$ & $0.714^{* * *}$ & $0.724^{* * *}$ \\
F test of ex. Instruments & $(0.017)$ & $(0.019)$ & $(0.019)$ \\
Number of observations & - & - & 68.23 \\
$\mathrm{R}^{2}$ & 34,633 & 19,809 & 19,046 \\
\hline
\end{tabular}

Notes: Municipality-level regressions for unemployment in the respective years of elections. Sample includes all municipalities without an own MDF. All regressions include municipality characteristics (surface, population, female population share, age structure of the population), county dummies, and year dummies. Distance related instruments are calculated from the geographic centroids of the municipalities. Clustered standard errors on the municipalitylevel. *** $1 \%$ significance level; ** $5 \%$ significance level; * $10 \%$ significance level. 